\title{
Indicators of Stress in Equitation
}

\author{
U. König v. Borstel ${ }^{1 *}$, E. K. Visser², C. Hall ${ }^{3}$
}

\author{
${ }^{1}$ Department of Animal Science, University of Göttingen, Albrecht-Thaer-Weg 3, 37075 Göttingen, \\ Germany \\ ${ }^{2}$ Horsonality, Skipper 3, 8456 JB De Knipe, The Netherlands \\ ${ }^{3}$ School of Animal Rural \& Environmental Sciences, Nottingham Trent University, Brackenhurst Campus, \\ Southwell, Nottinghamshire, NG25 0QF, UK \\ * corresponding author: koenigvb@gwdg.de
}

\section{Abstract}

Information on equine stress levels are important in evaluating many aspects of horse management and training. For example, for correct assessment of equine welfare, implications of training and handling procedures, success of training and the interpretation of equine temperament. Stress is a generic concept describing the body's reaction to external stimuli, including both physiological and psychological factors. Therefore, by definition, the assessment of psychological stress in the exercising horse encompasses the problem of teasing apart the psychological and physiological factors both of which result in stress responses. . The present paper reviews the existing literature on various measures of stress taken specifically in the context of equitation science. Particular attention has been paid to short-term effects, and commonly used measurements of short-term stress include heart rate, a number of heart rate variability parameters, blood or saliva cortisol levels, eye temperature, and various behaviour parameters including in particular behaviour patterns presumably indicative of conflict with the rider's/trainer's aids. Inspection of the individual studies' results revealed that disagreement between these different measures of stress is commonplace. For physiological parameters, the largest proportion of agreement (i.e. both parameters simultaneously indicated either higher, non- significant or lower stress compared to a control treatment) was found for heart rate and heart rate variability parameters, while generally limited agreement was found for cortisol and cardiovascular parameters. It appears that cortisol levels may not be particularly useful for assessment of the valence of a situation in the exercising horse as cortisol levels are predominantly linked to activity and exercise levels. Although heart rate variability parameters reflect in theory more closely sympathovagal balance compared to cortisol levels, great care has to be taken regarding the use of appropriate equipment, time-frames, as well as raw data correction. In spite of its wide-spread and apparently successful use, popular equipment may in fact not be accurate enough under 
field conditions. Eye temperature is another promising parameter for assessment of psychological stress, but the technique is likewise susceptible to application errors. Given the high susceptibility of physiological parameters to errors at various experimental stages, behavioural rather than physiological parameters may in fact provide more accurate measures of valence when conducting experiments in the exercising horse. Behavioural parameters that appear to be particularly practical in assessing stress in ridden horses' behaviour are frequencies of behaviour patterns indicative of conflict. However, while increased frequencies of behaviour patterns indicative of conflict are a good indicator of stress, the absence of conflict behaviour does not provide proof of the absence of stress due to the possible occurrence of conditions such as Learned Helplessness. In future studies, the above issues with the interpretation of indicators of stress should be taken into consideration when designing experiments to assess psychological stress in ridden horses.

Keywords: stress; horse; riding; heart rate variability; cortisol; behaviour

\section{Introduction}

Stress describes the organism's non-specific response to challenges. These challenges typically include situations that require or potentially require the individual to fight or flee, to cope with environmental conditions such as extreme temperatures (Rammersdorfer et al. 2001), or to cope with psychological challenges. The stress response functions to make energy available necessary to cope with these challenges. The stress response involves activation of the two main physiological pathways: the hypothalamic-pituitary-adrenal cortex axis (HPA) and the sympathetic-adrenal medulla (SAM) axis. As a result of the activation of the HPA and SAM, specific changes in the body take place which can be used to assess the degree of activation. However, the non-specificity of the stress response makes it difficult to tease apart different factors that contribute to the activation of physiological mechanisms involved with stress, and has led some researchers to suggest abandoning the term 'stress' altogether (Rushen, 1986). In the context of animal science, however, stress is commonly used to refer to psychological challenges only, excluding stress responses as a result of physiological challenges. As outlined below, it is in fact difficult, if not impossible, to entirely tease apart physiological and psychological factors resulting in stress. However, with regard to animal welfare, the psychological component, i.e. the valence a horse assigns to a situation, is the pivotal factor. Therefore, for the purpose of the present review, stress is, unless specified and referred to otherwise, defined as the psychological challenge that an individual experiences. 


\subsection{The stress response}

Information about the internal and external conditions is perceived by the organism through various receptors, and this information is relayed via the afferent nerves to the central nervous system where the information is processed (Tartaglia and Waugh, 2002). If a situation is perceived as a stressor, signals are sent through the efferent nerves to mediate responses of the somatic and autonomic nervous system, resulting in behavioural and physiological responses. Behavioural responses can be either active, i.e. the fight or flight reaction, or passive, such as freezing, hiding or exhibiting abnormal behaviour or stereotypies (Squires, 2003The sympathetic-adrenal medulla (SAM) axis is responsible for the immediate responses involving activation of the sympathetic branch of the autonomic nervous system, which leads to increased heart rate, increased blood pressure, reduced gastrointestinal activity, and increased secretion of the catecholamines adrenaline and noradrenaline (Squires, 2003). Adrenaline stimulates glycogenolysis (Squires 2003), thereby making energy available for the organism.

Longer-term effects are mediated through the HPA, whose activation is involved in the secretion of corticotrophin releasing hormone from the hypothalamus triggering increased secretion of adrenocorticotrophic hormone from the pituitary gland, which stimulates secretion of corticosteroids, such as cortisol and corticosterone from the adrenal cortex (Squires. 2003). These corticosteroids trigger the catabolic processes glycolysis, lipolysis, and in the case of prolonged, high levels, cortisol also causes the proliferation of gluconeogenesis from body proteins (Squires. 2003). Ultimately, this depletion of energy leads to decreased growth in juvenile animals or weight loss in mature animals. Cortisol also has effects on catecholamines with the result that glycogen is converted yet more readily to glucose. Besides energy regulating effects, cortisol also targets lymphoid cells and the thymus gland, not only leading to immunosuppression, but also anti-inflammatory effects. Furthermore, gastric secretion is increased by glucocorticoids, which can lead to the development of gastric ulcers. Also, the effects of luteinising hormone are blocked by cortisol, leading to decreased reproductive efficiency (Squires 2003). The extent to which the HPA and SAM pathways are activated in response to the same stressor differs considerably between horses. The way animals respond to stressors has been studied with reference to coping strategies, in which some animal species can be divided in very distinct classes representing active copers and reactive copers (Koolhaas et al., 2007). For horses these distinctions have not been shown (Visser, 2002), and it has been suggested that horses' different reactions to stressors are better described as continuously distributed traits rather than a trait with distinct categories (König v. Borstel, 2013). 


\subsection{Exercise, physiological and psychological stress}

Assessment of (psychological) stress has become one of the major research topics in equitation science. Information on equine stress levels are important e.g. for correct assessment of equine welfare, implications of training, handling procedures and transport, success of training and in the interpretation of equine temperament. However, the non-specificity of stress as a general concept as well as of the individual parameters indicative of stress constitutes a major challenge that is particularly relevant to equitation science which generally involves research in the exercising horse. Physical and psychological factors that may cause stress generally occur to some degree simultaneously, and may even be inherently confounded such as is the case with fear reactions which involve both emotional as well as physical components. Moreover, exercise per se appears to be to some degree stressful to the horse, as preference tests and associated measures of heart rate and behaviour indicate that horses generally show limited motivation for exercise (Lee et al., 2011; Górecka-Bruzda et al., 2012; König von Borstel and Keil, 2012). This is perhaps with the exception of small bouts of locomotory activity shown as rebound effects after deprivation from locomotion (Chaya et al., 2006; Kurvers et al., 2006; Freire et al., 2009) or in connection with play behaviour. Whether horses, as with humans, experience exercise-induced euphoria as a result of increased levels of endogenous opioids (Harber and Sutton, 1984) in response to prolonged exercise, is yet to be determined.

Under these (even if with horses, potentially rare) conditions, exercise does not necessarily have a negative emotional component, but may even lead to positive emotions. This conditionality of the perception of exercise indicates that the individual's attitude towards a given situation is important as to how it impacts on that individual That the subjective experience of a stressor is important in its effect on the organism has been demonstrated in studies on laboratory animals.. For example, Laudenslager et al. (1983) showed that lymphocyte proliferation was suppressed in rats after inescapable, but not after identical escapable, electric shocks. This indicates that the key factor that determines if a stressor has a negative, neutral, or even positive outcome, is whether an individual perceives itself to be in control of the situation or not.

In the absence of psychological stressors, physical exercise nevertheless results in the activation of the same stress pathways (HPA and SAM). However, in rats, stress due to repeated, moderate exercise leads to adaptation of the body to the demands, and ultimately improves the body's capacity to cope with stress (Lalanza et al., 2015). During psychological and non-exercise physical stress, the physiological and endocrine changes prepare the body for the fight or flight reaction, however, in many cases these actions 
do not actually follow, and therefore the mobilized energy is not used. In contrast, during exercise, the physiological and endocrine changes are accompanied by locomotion thus providing an outlet for the mobilized energy.

\subsection{Sources of stress related to equitation}

Besides the obvious physical stress placed on horses during equestrian activities due to the movement and the carrying of additional weight of the rider or when pulling a carriage, a number of factors have the potential to induce considerable psychological stress in the exercising horse. For example, horses are frequently exposed to novel stimuli, situations, and environments during equestrian activities, all of which are likely to induce neophobia. Therefore, one of the major stressors to the horse in training is fear or anxiety. Being a highly social animal, the horse is also very sensitive to the rider's or handler's emotional states (von Borstel and König, 2008), and consequently a nervous rider her or himself may in fact be a source of anxiety in the horse (von Borstel, 2008b; Keeling et al., 2009). Social separation as well as work in close proximity to unfamiliar horses may likewise frequently occur, both being likely to cause anxiety (Moons et al., 2005; Hartmann et al., 2011). Transportation often combines the effects of claustrophobia with neophobia, social separation and balancing (Doherty et al. 1997), and is therefore not surprisingly a frequently researched/investigated stressor in horses (Cregier, 1982; Baucus et al., 1990; Linden et al., 1991; Mars et al., 1992; Waran et al., 2002).

Pain and discomfort are other important sources of stress in the exercising horse. Apart from painful conditions such as lameness and back pain, ill-fitted tack and the effect of the rider (or equestrian trainer) are also potentially major sources of pain in the ridden horse. For example, according to Witzmann (2014), $64 \%$ of the objections with veterinary inspections during English riding competitions concerned horses' mouths. Other studies confirm the high prevalence of oral injuries found in horses in other equestrian disciplines (Mata et al., 2015; Visser et al., 2014 ). Damage to the mouth is most likely caused by severe bits and overly harsh use thereof by the rider. Depending on the nature of the stressor, different physiological and behavioural parameters may be useful to quantify the amount of stress experienced by the horse. The following section provides an overview of stress-related parameters commonly used in the context of equestrian activities, focussing on measures of short-term stress, which are particularly relevant in this context. In addition a brief overview of measures of long-term stress which also may be of interest to some equitation-related research questions, is provided. 


\section{Indicators of short-term stress used in equitation science}

A variety of potential stressors have been studied in the ridden (Table 1a) or otherwise exercising (Table 1b) horse, using a number of different parameters. Assessment of a stress response is clearly best carried out using a combination of both behavioural and physiological measures (Broom, 1991; Mason and Mendl, 1993; Dawkins, 2003). Clearly the behavioural and physiological measures must both be sufficiently sensitive and reliable to for effective use in a behavioural scale for welfare assessment (Visser et al., 2014). Useful measures include behaviour (Rivera et al., 2002; von Borstel et al., 2011), cardiovascular parameters (Rietmann et al., 2004b; Von Borell et al., 2007; Visser et al., 2008) and cortisol (Ralston et al., 1988; Toutain et al., 1995; McBride and Cuddeford, 2001; Covalesky et al., 1992; Stegman and Jones, 1998), as well as the more recently developed, eye temperature measures (Yarnell et al., 2013; Hall et al., 2014). Nevertheless, great care has to be taken when interpreting changes in these parameters as signs of stress, in particular if activity levels cannot be controlled for or if recommendations for recording (see Table 2 for a summary) are not observed. 
Table 1a Overview of studies assessing psychological stress in the ridden horse and description of test situation and parameters assessed. (HR = heart rate; RMSSD = root-mean square differences of successive beat-to-beat intervals; pNN50 = proportion of pairs of beat-to-beat intervals that differ by more than $50 \mathrm{~ms}$; SDNN = standard deviation of beat-to-beat intervals; $\mathrm{LF} / \mathrm{HF}=$ ratio of low to high frequency heart rate variability bands)

\begin{tabular}{|c|c|c|c|c|c|c|c|c|c|c|c|c|c|c|c|c|}
\hline Reference & Test situations & $\begin{array}{l}\text { Exercise } \\
\text { Level }\end{array}$ & $\begin{array}{l}\text { Duration } \\
\text { / Time } \\
\text { of } \\
\text { measure } \\
\text {-ment }\end{array}$ & 呈 & $\sum_{\propto}^{n}$ & $\begin{array}{l}\text { 은 } \\
\sum_{2}\end{array}$ & $\begin{array}{l}z \\
\text { n } \\
\text { n }\end{array}$ & 岌 & 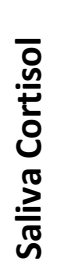 & 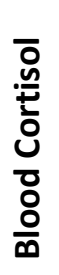 & 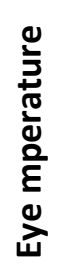 & 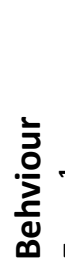 & $\begin{array}{l}\frac{1}{3} \\
\frac{0}{2} \\
\frac{0}{0} \\
\frac{c}{0} \\
\infty\end{array}$ & $\begin{array}{l}\frac{1}{3} \\
\frac{0}{2} \\
\frac{0}{0} \\
0 \\
0\end{array}$ & $\begin{array}{l}\text { Other } \\
\text { behavioural } \\
\text { and } \\
\text { performance } \\
\text { related } \\
\text { parameters }\end{array}$ & $\begin{array}{l}\text { Additional physiological } \\
\text { parameters }\end{array}$ \\
\hline $\begin{array}{l}\text { Normando } \\
\text { et al., } \\
2011\end{array}$ & $\begin{array}{l}\text { Questionnaire } \\
\text { on problem } \\
\text { behaviour }\end{array}$ & $\begin{array}{l}\text { walk, } \\
\text { trot, } \\
\text { canter }\end{array}$ & $\begin{array}{l}\text { long- } \\
\text { term } \\
\text { (years) }\end{array}$ & - & - & - & - & - & - & - & - & - & - & - & $\begin{array}{l}\text { stereotypies, } \\
\text { problem } \\
\text { behaviour }\end{array}$ & - \\
\hline $\begin{array}{l}\text { v. Borstel } \\
\text { et al., } \\
2009\end{array}$ & $\begin{array}{l}\text { head and neck } \\
\text { postures }\end{array}$ & $\begin{array}{l}\text { walk, } \\
\text { trot }\end{array}$ & $\begin{array}{l}15 \times 1 \\
\text { minute }\end{array}$ & $x$ & - & - & - & - & - & - & - & $x$ & - & - & preference & - \\
\hline $\begin{array}{l}\text { Egenvall } \\
\text { et al., } \\
2012\end{array}$ & $\begin{array}{l}\text { trot-walk } \\
\text { transitions }\end{array}$ & $\begin{array}{l}\text { walk, } \\
\text { trot }\end{array}$ & $\begin{array}{l}5 \\
\text { seconds }\end{array}$ & - & - & - & - & - & - & - & - & - & $x$ & - & $\begin{array}{l}\text { learning } \\
\text { speed, rein } \\
\text { tension }\end{array}$ & - \\
\hline $\begin{array}{l}\text { Gorecka- } \\
\text { Bruzda } \\
\text { et al., } \\
2015\end{array}$ & $\begin{array}{l}\text { Dressage vs } \\
\text { show jumping }\end{array}$ & $\begin{array}{l}\text { halt, } \\
\text { walk, } \\
\text { trot, } \\
\text { canter }\end{array}$ & $\begin{array}{l}1-10 \\
\text { minutes }\end{array}$ & - & - & - & - & - & - & - & - & $x$ & $x$ & - & - & - \\
\hline $\begin{array}{l}\text { Hall } \\
\text { et al., } \\
2014\end{array}$ & Dressage test & $\begin{array}{l}\text { walk, } \\
\text { trot, } \\
\text { canter }\end{array}$ & $\begin{array}{l}2-3 \\
\text { minutes }\end{array}$ & - & - & - & - & - & $x$ & - & $x$ & - & $x$ & - & - & - \\
\hline
\end{tabular}

\footnotetext{
${ }^{1}$ Frequency of conflict behaviour

${ }^{2}$ Duration of behaviour/postures

${ }^{3}$ Behaviour score/visual analogue scale
} 


\begin{tabular}{|c|c|c|c|c|c|c|c|c|c|c|c|c|c|c|c|c|}
\hline $\begin{array}{l}\text { Heleski } \\
\text { et al., } \\
2009\end{array}$ & $\begin{array}{l}\text { Effect of } \\
\text { martingales } \\
\text { and elastic rein } \\
\text { inserts }\end{array}$ & $\begin{array}{l}\text { walk, } \\
\text { trot }\end{array}$ & $\begin{array}{l}30 \\
\text { seconds }\end{array}$ & - & - & - & - & - & - & - & - & $x$ & - & - & rein tension & - \\
\hline $\begin{array}{l}\text { Kaiser } \\
\text { et al., } \\
2006\end{array}$ & $\begin{array}{l}\text { regular and } \\
\text { therapy riding } \\
\text { sessions }\end{array}$ & $\begin{array}{l}\text { walk, } \\
\text { trot, } \\
\text { canter }\end{array}$ & $\begin{array}{l}1 \text { hour (2 } \\
\text { minutes) }\end{array}$ & - & - & - & - & - & - & - & - & $x$ & - & - & - & - \\
\hline $\begin{array}{l}\text { Kienapfel } \\
\text { et al., } \\
2014\end{array}$ & $\begin{array}{l}\text { head and neck } \\
\text { postures }\end{array}$ & $\begin{array}{l}\text { walk, } \\
\text { trot, } \\
\text { canter }\end{array}$ & $\begin{array}{l}3 \\
\text { minutes }\end{array}$ & - & - & - & - & - & - & - & - & $x$ & - & - & - & - \\
\hline $\begin{array}{l}\text { Kienapfel, } \\
2011\end{array}$ & $\begin{array}{l}\text { head and neck } \\
\text { postures }\end{array}$ & $\begin{array}{l}\text { walk, } \\
\text { trot, } \\
\text { canter }\end{array}$ & $\begin{array}{l}3 \\
\text { minutes }\end{array}$ & - & - & - & - & - & - & - & - & $x$ & - & - & - & - \\
\hline $\begin{array}{l}\text { König v. } \\
\text { Borstel } \\
\text { and } \\
\text { Glißmann, } \\
2014\end{array}$ & $\begin{array}{l}\text { young horse } \\
\text { performance } \\
\text { test }\end{array}$ & $\begin{array}{l}\text { halt, } \\
\text { walk, } \\
\text { trot, } \\
\text { canter }\end{array}$ & $\begin{array}{l}\text { ca. } 20 \\
\text { minutes }\end{array}$ & - & - & - & - & - & - & - & - & $x$ & $x$ & $x$ & $\begin{array}{l}\text { rein tension, } \\
\text { rideability }\end{array}$ & - \\
\hline $\begin{array}{l}\text { LeSimple } \\
\text { et al., } \\
2010\end{array}$ & Riding lessions & $\begin{array}{l}\text { walk, } \\
\text { trot, } \\
\text { canter }\end{array}$ & $\begin{array}{l}\text { instanta } \\
\text { neous ( } \\
\text { 1hour) }\end{array}$ & - & - & - & - & - & - & - & - & - & $x$ & - & $\begin{array}{l}\text { chiropractic } \\
\text { assessment } \\
\text { of back pain }\end{array}$ & - \\
\hline $\begin{array}{l}\text { Peeters } \\
\text { et al., } \\
2013\end{array}$ & $\begin{array}{l}\text { Show-jumping } \\
\text { competition; } \\
\text { comparison of } \\
\text { horse and } \\
\text { rider stress }\end{array}$ & $\begin{array}{l}\text { (walk, } \\
\text { trot), } \\
\text { canter }\end{array}$ & $\begin{array}{l}1-3 \\
\text { minutes, } \\
\text { samples } \\
\text { taken } \\
\text { before } \\
\text { and } 20, \\
40 \text {, and } \\
60 \text { after } \\
\text { test }\end{array}$ & - & - & - & - & - & $x$ & - & - & - & - & - & $\begin{array}{l}\text { performance } \\
\text { (penalty } \\
\text { points) }\end{array}$ & - \\
\hline $\begin{array}{l}\text { Valera } \\
\text { et al., } \\
2012\end{array}$ & $\begin{array}{l}\text { Show-jumping } \\
\text { competition }\end{array}$ & canter & $\begin{array}{l}-3 \mathrm{~h},- \\
\text { and } 5 \\
\text { minutes } \\
\text { past test }\end{array}$ & - & - & - & - & - & $x$ & - & $x$ & - & . & - & - & - \\
\hline
\end{tabular}




\begin{tabular}{|c|c|c|c|c|c|c|c|c|c|c|c|c|c|c|c|c|}
\hline $\begin{array}{l}\text { Vanderhor } \\
\text { st et al., } \\
2013\end{array}$ & 2 bits & $\begin{array}{l}\text { walk, } \\
\text { trot, } \\
\text { canter }\end{array}$ & $\begin{array}{l}\text { ca. } 5 \\
\text { minutes }\end{array}$ & $(x)$ & $x$ & - & - & - & - & - & - & $x$ & $(x)$ & - & $\begin{array}{l}\text { tongue } \\
\text { colour, } \\
\text { quantitiy of } \\
\text { visible saliva }\end{array}$ & - \\
\hline $\begin{array}{l}\text { Christense } \\
\text { n et al., } \\
2013\end{array}$ & $\begin{array}{l}\text { head and neck } \\
\text { postures }\end{array}$ & $\begin{array}{l}\text { walk, } \\
\text { trot, } \\
\text { canter }\end{array}$ & $\begin{array}{l}10 \\
\text { minutes }\end{array}$ & $x$ & $x$ & - & - & $x$ & $x$ & - & - & $x$ & $x$ & - & rein tension & - \\
\hline $\begin{array}{l}\text { Fazio et } \\
\text { al., } 2013\end{array}$ & $\begin{array}{l}\text { Therapeutic vs } \\
\text { recreational } \\
\text { riders }\end{array}$ & walk & $\begin{array}{l}5 \text { and } 30 \\
\text { minutes } \\
\text { after } \\
\text { exercise }\end{array}$ & $x$ & - & - & - & - & - & $x$ & - & - & - & - & - & $\begin{array}{l}\text { basal beta-endorphin } \\
\text { levels, ACTH, lactate }\end{array}$ \\
\hline $\begin{array}{l}\text { Ferlazzo et } \\
\text { al., } 2012\end{array}$ & $\begin{array}{l}\text { levels of show- } \\
\text { jumping }\end{array}$ & canter & $\begin{array}{l}\text { before } \\
\text { and } 5+ \\
30 \text { min } \\
\text { after test }\end{array}$ & $x$ & - & - & - & - & - & $x$ & - & - & - & - & $\begin{array}{l}\text { performance } \\
\text { (time, } \\
\text { penalty } \\
\text { points) }\end{array}$ & $\begin{array}{l}\text { beta-endorphine levels, } \\
\text { ACTH }\end{array}$ \\
\hline $\begin{array}{l}\text { König v. } \\
\text { Borstel } \\
\text { and Keil, } \\
2012\end{array}$ & $\begin{array}{l}\text { lengths of } \\
\text { riding bouts }\end{array}$ & $\begin{array}{l}\text { walk, } \\
\text { trot }\end{array}$ & 1 minute & $x$ & - & - & - & - & - & - & - & $x$ & - & - & preference & - \\
\hline $\begin{array}{l}\text { v. Borstel } \\
\text { et al., } 2011\end{array}$ & $\begin{array}{l}\text { stallion } \\
\text { performance } \\
\text { test }\end{array}$ & $\begin{array}{l}\text { halt, } \\
\text { walk, } \\
\text { trot, } \\
\text { canter }\end{array}$ & $\begin{array}{l}\text { ca. } 20 \\
\text { minutes }\end{array}$ & $x$ & $x$ & - & - & $x$ & - & - & - & $x$ & $x$ & $x$ & $\begin{array}{l}\text { rider } \\
\text { behaviour }\end{array}$ & - \\
\hline $\begin{array}{l}\text { Medica et } \\
\text { al., } 2011\end{array}$ & $\begin{array}{l}\text { different } \\
\text { stages of } \\
\text { Western riding } \\
\text { training }\end{array}$ & $\begin{array}{l}\text { trot, } \\
\text { canter, } \\
\text { gallop }\end{array}$ & $\begin{array}{l}30 \\
\text { minutes }\end{array}$ & $x$ & - & - & - & - & - & $x$ & - & - & - & - & - & $\begin{array}{l}\text { iodothyronine, oestradiol- } \\
17 \mathrm{~b}\end{array}$ \\
\hline $\begin{array}{l}\text { Munsters } \\
\text { et al., } 2012\end{array}$ & $\begin{array}{l}\text { Novel object } \\
\text { tests with } \\
\text { different } \\
\text { horse-rider } \\
\text { matches }\end{array}$ & walk & $\begin{array}{l}5 \\
\text { minutes }\end{array}$ & $x$ & $?$ & - & - & - & - & - & - & - & - & $x$ & - & - \\
\hline
\end{tabular}




\begin{tabular}{|c|c|c|c|c|c|c|c|c|c|c|c|c|c|c|c|c|}
\hline $\begin{array}{l}\text { Munsters } \\
\text { et al., } 2013\end{array}$ & $\begin{array}{l}\text { Different parts } \\
\text { of police horse } \\
\text { work }\end{array}$ & $\begin{array}{l}\text { halt, } \\
\text { walk, } \\
\text { trot, } \\
\text { canter }\end{array}$ & $\begin{array}{l}1-5 \\
\text { hours }\end{array}$ & $x$ & - & - & - & - & - & - & - & - & - & $x$ & - & $\begin{array}{l}\text { peak heart rates, plasma } \\
\text { lactate }\end{array}$ \\
\hline $\begin{array}{l}\text { Powell et } \\
\text { al., } 2008\end{array}$ & $\begin{array}{l}\text { Different } \\
\text { weight loads }\end{array}$ & $\begin{array}{l}\text { trot, } \\
\text { canter }\end{array}$ & . & $x$ & - & - & - & - & - & - & - & - & - & - & $\begin{array}{l}\text { muscle } \\
\text { soreness, } \\
\text { muscle } \\
\text { tightness } \\
\text { scores }\end{array}$ & $\begin{array}{l}\text { plasma lactate, serum } \\
\text { creatine kinase activity }\end{array}$ \\
\hline $\begin{array}{l}\text { Sloet et al., } \\
2006\end{array}$ & $\begin{array}{l}\text { head and neck } \\
\text { postures }\end{array}$ & $\begin{array}{l}\text { trot, } \\
\text { canter }\end{array}$ & $\begin{array}{l}6 \\
\text { minutes }\end{array}$ & $x$ & - & - & - & - & - & $x$ & - & - & - & - & $\begin{array}{l}\text { riders' } \\
\text { subjective } \\
\text { impression }\end{array}$ & $\begin{array}{l}\text { blood lactate, packed cell } \\
\text { volume, pH, bicarbonate, } \\
\text { pC02, Glucose, } \\
\text { electrolytes, creatinine } \\
\text { kinase, }\end{array}$ \\
\hline $\begin{array}{l}\text { van Breda, } \\
2006\end{array}$ & $\begin{array}{l}\text { Dressage vs } \\
\text { recreational } \\
\text { horses }\end{array}$ & $\begin{array}{l}\text { halt } \\
\text { after } \\
\text { exercise }\end{array}$ & $\begin{array}{l}\text { for } 10 \\
\text { minutes } \\
30-45 \\
\text { min after } \\
\text { test }\end{array}$ & $x$ & $x$ & - & - & $x$ & - & - & - & - & - & - & - & total HF and LF \\
\hline $\begin{array}{l}\text { von } \\
\text { Lewinski et } \\
\text { al., } 2013\end{array}$ & $\begin{array}{l}\text { Competition vs } \\
\text { training }\end{array}$ & $\begin{array}{l}\text { halt, } \\
\text { walk, } \\
\text { trot, } \\
\text { canter }\end{array}$ & $\begin{array}{l}\text { before, } \\
0,15 \\
\text { min past } \\
\text { test }\end{array}$ & $x$ & $x$ & - & $x$ & - & $x$ & - & - & - & - & - & - & - \\
\hline $\begin{array}{l}\text { Zebisch et } \\
\text { al., } 2014\end{array}$ & $\begin{array}{l}\text { head and neck } \\
\text { postures }\end{array}$ & $\begin{array}{l}\text { trot, } \\
\text { canter }\end{array}$ & $\begin{array}{l}15 \\
\text { minutes }\end{array}$ & $x$ & - & - & - & $x$ & - & $x$ & - & - & - & $x$ & - & HF, LF power \\
\hline $\begin{array}{l}\text { König v. } \\
\text { Borstel et } \\
\text { al., } 2011\end{array}$ & $\begin{array}{l}\text { Novel objects, } \\
\text { startle }\end{array}$ & walk & $\begin{array}{l}10 \\
\text { seconds }\end{array}$ & $x$ & $x$ & $x$ & - & - & - & - & - & - & $x$ & $x$ & - & - \\
\hline
\end{tabular}


Table $\mathbf{1 b}$ Overview of studies assessing psychological stress in the horse in relation to training, handling or exercise and description of test situation and parameters assessed (HR = heart rate; RMSSD = root-mean square differences of successive beat-to-beat intervals; pNN50 = proportion of pairs of beat-to-beat intervals that differ by more than 50 ms; SDNN = standard deviation of beat-to-beat intervals; LF/HF = ratio of low to high frequency bands)

\begin{tabular}{|c|c|c|c|c|c|c|c|c|c|c|c|c|c|c|c|c|c|}
\hline Reference & $\begin{array}{l}\text { Test } \\
\text { situations }\end{array}$ & $\begin{array}{l}\text { Type of } \\
\text { work }\end{array}$ & $\begin{array}{l}\text { Excercis } \\
\text { e level }\end{array}$ & $\begin{array}{l}\text { Duration/ } \\
\text { Time of } \\
\text { measure- } \\
\text { ment }\end{array}$ & 敛 & 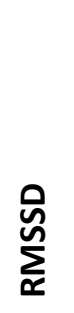 & $\sum_{2}^{0}$ & ż & 岂 & 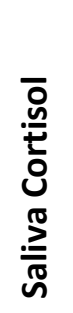 & 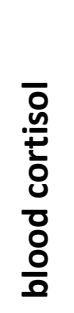 & 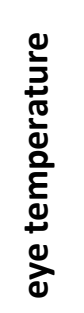 & 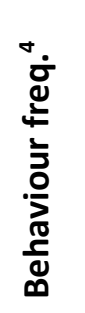 & 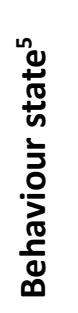 & 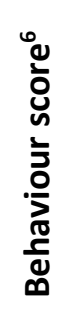 & $\begin{array}{l}\text { Other } \\
\text { behavioural } \\
\text { and } \\
\text { performance } \\
\text { related } \\
\text { parameters }\end{array}$ & $\begin{array}{l}\text { Additional } \\
\text { physiological } \\
\text { parameters }\end{array}$ \\
\hline $\begin{array}{l}\text { Rivera et } \\
\text { al., } 2002\end{array}$ & $\begin{array}{l}\text { Pastured } \\
\text { vs. Stabled } \\
\text { horses }\end{array}$ & $\begin{array}{l}\text { Training } \\
\text { to } \\
\text { mountin } \\
\text { g, Riding }\end{array}$ & $\begin{array}{l}\text { halt, } \\
\text { walk, } \\
\text { trot, } \\
\text { canter }\end{array}$ & $\begin{array}{l}\text { variable, } \\
\text { ca. } 10-50 \\
\text { minutes }\end{array}$ & - & - & - & - & - & - & $x$ & - & $x$ & - & - & - & - \\
\hline $\begin{array}{l}\text { Janczarek } \\
\text { et al., } \\
2013\end{array}$ & $\begin{array}{l}\text { Initial } \\
\text { training; } \\
\text { breed } \\
\text { compariso } \\
\text { n }\end{array}$ & $\begin{array}{l}\text { Tacking } \\
\text { and } \\
\text { mountin } \\
\mathrm{g}\end{array}$ & $\begin{array}{l}\text { halt, } \\
\text { walk }\end{array}$ & $\begin{array}{l}30-60 \\
\text { minutes }\end{array}$ & $x$ & - & - & - & - & - & - & - & - & - & - & $\begin{array}{l}\text { learning } \\
\text { speed }\end{array}$ & $\begin{array}{l}\text { duration of } H R>100 \\
\text { bpm }\end{array}$ \\
\hline $\begin{array}{l}\text { Malinows } \\
\text { ki et al., } \\
2006\end{array}$ & $\begin{array}{l}\text { acute } \\
\text { exercie }\end{array}$ & $\begin{array}{l}\text { Treadmi } \\
\text { II }\end{array}$ & $\begin{array}{l}\text { Indivi- } \\
\text { duals' } \\
\text { maxi- } \\
\text { mum } \\
\text { speed }\end{array}$ & $\begin{array}{l}>2 \\
\text { minutes }\end{array}$ & $x$ & - & - & - & - & - & $x$ & - & - & - & - & - & $\begin{array}{l}\text { beta-endorphin, } \\
\text { oxygen uptake, blood } \\
\text { leucocyte numbers } \\
\text { and immune cell } \\
\text { subsets, lymphocyte } \\
\text { proliferation response }\end{array}$ \\
\hline
\end{tabular}

\footnotetext{
${ }^{4}$ frequency of conflict behaviour

${ }^{5}$ duration of behaviour/postures

${ }^{6}$ behaviour score/visual analogue scale
} 


\begin{tabular}{|c|c|c|c|c|c|c|c|c|c|c|c|c|c|c|c|c|c|}
\hline $\begin{array}{l}\text { De } \\
\text { Rantere } \\
\text { et al., } \\
2007\end{array}$ & $\begin{array}{l}\text { Two } \\
\text { different } \\
\text { degrees of } \\
\text { poll flexion }\end{array}$ & $\begin{array}{l}\text { Treadmi } \\
\text { II }\end{array}$ & trot & 7 minutes & $x$ & - & - & - & - & - & - & - & $x$ & - & - & - & $\begin{array}{l}\mathrm{pO} 2, \mathrm{pCO} 2, \mathrm{HCO} 3, \mathrm{pH} \text {, } \\
\mathrm{BE}, \mathrm{PCV} \text {, lactate, } \\
\text { glucose }\end{array}$ \\
\hline $\begin{array}{l}\text { Kienapfel, } \\
2011\end{array}$ & $\begin{array}{l}\text { head and } \\
\text { neck } \\
\text { postures }\end{array}$ & $\begin{array}{l}\text { Standin } \\
\mathrm{g}\end{array}$ & halt & $\begin{array}{l}10 \\
\text { seconds }\end{array}$ & - & - & - & - & - & - & - & - & $x$ & - & - & - & - \\
\hline $\begin{array}{l}\text { McGreevy } \\
\text { et al., } \\
2012\end{array}$ & $\begin{array}{l}\text { double } \\
\text { bridle with } \\
\text { or without } \\
\text { noseband }\end{array}$ & $\begin{array}{l}\text { Standin } \\
\mathrm{g}\end{array}$ & halt & $\begin{array}{l}10 \\
\text { minutes }\end{array}$ & - & - & - & - & - & - & - & $x$ & - & - & - & - & facial temperature \\
\hline $\begin{array}{l}\text { Schmidt } \\
\text { et al., } \\
2010\end{array}$ & $\begin{array}{l}\text { Stages of } \\
\text { initial } \\
\text { riding } \\
\text { training }\end{array}$ & $\begin{array}{l}\text { Lunging, } \\
\text { riding, } \\
\text { free }\end{array}$ & $\begin{array}{l}\text { halt, } \\
\text { walk, } \\
\text { trot, } \\
\text { canter }\end{array}$ & $\begin{array}{l}10-20 \\
\text { minutes }\end{array}$ & $x$ & $x$ & - & $x$ & - & $x$ & - & - & - & - & - & - & SD1, SD2 \\
\hline $\begin{array}{l}\text { Becker- } \\
\text { Birck et } \\
\text { al., } 2013\end{array}$ & $\begin{array}{l}\text { head and } \\
\text { neck } \\
\text { postures }\end{array}$ & Lunging & $\begin{array}{l}\text { walk, } \\
\text { trot, } \\
\text { canter }\end{array}$ & $\begin{array}{l}13 \\
\text { minutes; } \\
\text { HRV } \\
\text { measure } \\
\text { ments: } 5 \\
\text { minutes }\end{array}$ & $x$ & $x$ & - & $x$ & - & $x$ & - & - & - & - & - & - & $\begin{array}{l}\text { superficial } \\
\text { temperature of head } \\
\text { and neck }\end{array}$ \\
\hline $\begin{array}{l}\text { Visser et } \\
\text { al., } 2002\end{array}$ & $\begin{array}{l}\text { Training vs } \\
\text { no training }\end{array}$ & $\begin{array}{l}\text { Leading, } \\
\text { free }\end{array}$ & walk & . & . & . & . & . & . & . & . & . & . & . & . & - & - \\
\hline $\begin{array}{l}\text { Rietmann } \\
\text { et al., } \\
2004 b\end{array}$ & $\begin{array}{l}\text { Backwards } \\
\text { vs. } \\
\text { Forward } \\
\text { walking }\end{array}$ & Leading & $\begin{array}{l}\text { walk } \\
\text { (forwar } \\
\text { d and } \\
\text { backwar } \\
\text { ds) }\end{array}$ & $\begin{array}{l}20 \\
\text { minutes; } \\
\text { HRV for } \\
\text { mean of } \\
130-165 \\
\text { heart } \\
\text { beats }\end{array}$ & $x$ & - & - & - & $x$ & - & - & - & $x$ & $x$ & - & - & total HF and LF nu \\
\hline
\end{tabular}




\begin{tabular}{|c|c|c|c|c|c|c|c|c|c|c|c|c|c|c|c|c|c|}
\hline $\begin{array}{l}\text { Flemming } \\
\text { et al., } \\
2013\end{array}$ & $\begin{array}{l}\text { Veterinary } \\
\text { check } \\
\text { during } \\
\text { endurance } \\
\text { rides }\end{array}$ & Leading & $\begin{array}{l}\text { halt, } \\
\text { trot }\end{array}$ & $\begin{array}{l}45-70 \\
\text { seconds }\end{array}$ & - & - & - & - & - & - & - & - & - & - & $x$ & $\begin{array}{l}\text { performance } \\
\text { (ranking in } \\
\text { competition) }\end{array}$ & - \\
\hline $\begin{array}{l}\text { Kedzierski } \\
\text { et al., } \\
2012\end{array}$ & $\begin{array}{l}\text { different } \\
\text { training } \\
\text { methods }\end{array}$ & $\begin{array}{l}\text { Handlin } \\
\text { g, } \\
\text { lunging, } \\
\text { tacking, } \\
\text { mountin } \\
\text { g }\end{array}$ & $\begin{array}{l}\text { halt, } \\
\text { walk, } \\
\text { trot, } \\
\text { canter }\end{array}$ & 1 hour & $x$ & - & - & - & - & - & - & - & - & - & - & - & - \\
\hline $\begin{array}{l}\text { Gehrke et } \\
\text { al., } 2011\end{array}$ & $\begin{array}{l}\text { Pasture; } \\
\text { equine } \\
\text { assisted } \\
\text { therapy }\end{array}$ & $\begin{array}{l}\text { Free } \\
\text { movem } \\
\text { ent }\end{array}$ & $\begin{array}{l}\text { lying, } \\
\text { halt, } \\
\text { walk }\end{array}$ & 24 hours & $x$ & $x$ & - & $x$ & $x$ & - & - & - & - & - & - & - & SDNNindex \\
\hline $\begin{array}{l}\text { Quick and } \\
\text { Warren- } \\
\text { Smith, } \\
2009\end{array}$ & $\begin{array}{l}\text { Bitted vs } \\
\text { bitless } \\
\text { bridles }\end{array}$ & $\begin{array}{l}\text { Bitting, } \\
\text { Longrei } \\
\text { ning, } \\
\text { Riding }\end{array}$ & $\begin{array}{l}\text { walk, } \\
\text { trot, } \\
\text { canter }\end{array}$ & $\begin{array}{l}10 \\
\text { minutes }\end{array}$ & $x$ & - & - & - & - & - & - & - & $x$ & - & - & $\begin{array}{l}\text { frequency of } \\
\text { chewing }\end{array}$ & $\begin{array}{l}\text { "heart rate variability" } \\
\text { (defined as the } \\
\text { number of changes of } \\
\text { heart rate during the } \\
\text { test period, however } \\
\text { the sampling } \\
\text { frequency of the } \\
\text { monitor is not } \\
\text { reported) }\end{array}$ \\
\hline $\begin{array}{l}\text { Smiet et } \\
\text { al., } 2014\end{array}$ & $\begin{array}{l}\text { head and } \\
\text { neck } \\
\text { postures }\end{array}$ & $?$ & $\begin{array}{l}\text { walk, } \\
\text { trot, } \\
\text { canter }\end{array}$ & $\begin{array}{l}34 \\
\text { minutes }\end{array}$ & - & - & - & - & - & $x$ & - & - & $x$ & $x$ & - & - & - \\
\hline
\end{tabular}


Table 2. Recommendations for use of commonly used parameters in (short-term) stress research. (RMSSD = root-mean square differences of successive beat-to-beat intervals; SDNN = standard deviation of beat-to-beat intervals; pNN50 = proportion of pairs of beat-to-beat intervals that differ by more than $50 \mathrm{~ms} \mathrm{LF}=$ low frequency band; $\mathrm{HF}=$ high frequency bands)

\begin{tabular}{|c|c|c|c|}
\hline Parameter & $\begin{array}{l}\text { Factors to control for; best } \\
\text { practice for recording }\end{array}$ & Practical considerations & $\begin{array}{l}\text { Recommended } \\
\text { sampling time } \\
\text { or interval }\end{array}$ \\
\hline Heart rate & $\begin{array}{l}\text { - } \\
\text { - } \text { crosercise level } \\
\text { at minimum with another } \\
\text { device but preferably with } \\
\text { an ECG-recorder } \\
\text { - } \quad \text { use approved method of } \\
\text { artifact removal in raw data }\end{array}$ & $\begin{array}{l}\text { - } \\
\text { Thick winter coats and } \\
\text { - } \quad \text { battery failure in low } \\
\text { temperatures } \\
\text { - } \quad \text { liberally apply moistening } \\
\text { gel to enhance contact }\end{array}$ & Instantaneous \\
\hline RMSSD & $\begin{array}{l}\text { See heart rate - exact } \\
\text { recording is even more } \\
\text { important with heart rate } \\
\text { variability parameters than } \\
\text { with plain heart rate } \\
\text { correct for heart rate if } \\
\text { activity levels not controlled } \\
\text { for }\end{array}$ & $\begin{array}{l}\text { - See heart rate } \\
\text { - Highly correlated to pNN50; } \\
\text { RMSSD preferred due to } \\
\text { better statistical properties } \\
\text { (TFTESC, 1996) }\end{array}$ & $\begin{array}{l}5 \text { min. } \\
\text { (do not } \\
\text { compare } \\
\text { segments of } \\
\text { different } \\
\text { durations) }\end{array}$ \\
\hline pNN50 & - See RMSSD & - Use RMSSD instead & See RMSSD \\
\hline SDNN & - $\quad$ See RMSSD & $\begin{array}{l}\text { Depends on length of } \\
\text { recording time }\end{array}$ & $5 \mathrm{~min}$ or $24 \mathrm{~h}$ \\
\hline $\begin{array}{l}\text { LF/HF; } \\
\text { Normalized } \\
\text { LF } \\
\text { Normalized } \\
\text { HF }\end{array}$ & $\begin{array}{l}\text { - see heart rate } \\
\text { use suitable band widths (see } \\
\text { section } 2.1 .2 .2 \text { ) }\end{array}$ & - $\quad$ See heart rate and RMSSD & $\begin{array}{l}\geq 1 \min (\mathrm{HF}) \\
\geq 2 \mathrm{~min} \text { (LF) } \\
5 \text { min re- } \\
\text { commended for } \\
\text { standardization } \\
\text { purposes }\end{array}$ \\
\hline $\begin{array}{l}\text { Plasma } \\
\text { cortisol }\end{array}$ & $\begin{array}{l}\text { - } \quad \text { Exercise level } \\
\text { - } \quad \text { Time of day } \\
\text { - use baseline-treatment } \\
\text { differences rather than } \\
\text { absolute values } \\
\text { use profiles rather than } \\
\text { single measurements (see } \\
\text { section 2.2.1) }\end{array}$ & $\begin{array}{l}\text { Ensure proper and equal } \\
\text { sample handling and } \\
\text { processing (e.g. immediate } \\
\text { cooling) } \\
\text { different Kits assess } \\
\text { different fractions of } \\
\text { corticosteroids, so } \\
\text { comparisons across studies } \\
\text { not possible }\end{array}$ & $\begin{array}{l}\text { Instantaneous; } \\
\text { before + after } \\
\text { treatment }\end{array}$ \\
\hline
\end{tabular}




\begin{tabular}{|c|c|c|c|}
\hline $\begin{array}{l}\text { Saliva } \\
\text { cortisol }\end{array}$ & - See plasma cortisol & $\begin{array}{l}\text { Dilution effects depending } \\
\text { on amount of saliva } \\
\text { possible }\end{array}$ & $\begin{array}{l}\text { Ca. } 10-15 \mathrm{~min} \\
\text { after event } \\
\text { (cortisol reaches } \\
\text { saliva via } \\
\text { passive } \\
\text { diffusion) }\end{array}$ \\
\hline $\begin{array}{l}\text { Faecal } \\
\text { cortisol }\end{array}$ & - See plasma cortisol & $\begin{array}{l}\text { Dilution effects depending } \\
\text { on amount of gut fill } \\
\text { possible (but not yet } \\
\text { proven) }\end{array}$ & $\begin{array}{l}\text { Ca. } 24 \mathrm{~h} \text { after } \\
\text { event; or use } \\
\text { pooled samples } \\
\text { for long-term } \\
\text { stress }\end{array}$ \\
\hline Hair cortisol & $\begin{array}{l}\text { - Standardize hair length } \\
\text { starting from root. Local } \\
\text { cortisol production may be } \\
\text { present and confound } \\
\text { results }\end{array}$ & $\begin{array}{l}\text { Consider possible seasonal } \\
\text { (and other temporal) } \\
\text { differences in hair growth }\end{array}$ & \\
\hline $\begin{array}{l}\text { Eye temper- } \\
\text { ature }\end{array}$ & $\begin{array}{l}\text { - } \text { ambient conditions } \\
\text { (particularly avoid direct } \\
\text { sunlight) } \\
\text { - } \text { coat colour } \\
\text { - } \text { surface moisture }\end{array}$ & $\begin{array}{l}\text { check accuracy of camera } \\
\text { before test } \\
\text { - always keep the same } \\
\text { distance between camera } \\
\text { and eye }\end{array}$ & instantaneous \\
\hline $\begin{array}{l}\text { Frequencies } \\
\text { of conflict } \\
\text { behaviour }\end{array}$ & $\begin{array}{l}\text { - Use exact and reproducible } \\
\text { descriptions of behaviour } \\
\text { patterns } \\
\text { - Validate novel parameters } \\
\text { by assessing intra- and } \\
\text { inter-observer reliability }\end{array}$ & $\begin{array}{l}\text { - Use of video recordings } \\
\text { beneficial; also see Pierard } \\
\text { et al., } 2015 \text { for } \\
\text { recommendations on best } \\
\text { practice }\end{array}$ & instantaneous \\
\hline $\begin{array}{l}\text { Duration of } \\
\text { behavioural } \\
\text { states/ } \\
\text { postures }\end{array}$ & $\begin{array}{l}\text { - See frequencies of conflict } \\
\text { behaviour }\end{array}$ & $\begin{array}{l}\text { - Use of video recordings } \\
\text { highly recommended }\end{array}$ & instantaneous \\
\hline $\begin{array}{l}\text { Subjective } \\
\text { Behaviour } \\
\text { assessment }\end{array}$ & $\begin{array}{l}\text { - See frequencies of conflict } \\
\text { behaviour }\end{array}$ & $\begin{array}{l}\text { - Use of video recordings } \\
\text { highly recommended }\end{array}$ & instantaneous \\
\hline
\end{tabular}




\subsection{Cardiovascular parameters}

Changes in heart rate or blood pressure, representing autonomic responses, are frequently used to assess stress. Adrenaline results in increased heart rate and force of contraction of the heart, as well as dilatation of arteries to enhance blood flow through skeletal muscles and bronchioles (Myrtek, 2004). Noradrenaline causes constriction of veins and arteries particularly in the skin and the digestive system (Myrtek, 2004) leading to reduced blood supply and therefore temporally reduced functioning of these organs.

\subsubsection{Heart rate}

Heart rate is one of the most sensitive, non-invasive psychophysiological parameters. It can be a very informative measure of both physiological and psychological states of an individual when the other various factors that can influence heart rate are controlled. Factors influencing heart rate in mammals include physical factors such as exercise (conditioning status, duration and intensity of the exercise bout), postural changes, ambient temperature, and changes in altitude and humidity (Evans et al., 1977; Myrtek, 2004). To a lesser degree than physiological workload, heart rate is also a sensitive indicator of the arousal of the autonomous nervous system (Myrtek, 2004). Therefore, factors such as emotion per se (Visser et al., 2002), mental activation, stress or motivational states such as thirst, hunger and pain (Cannon, 1953) affect heart rate. Of the different emotions in human beings, fear, anger, anxiety and sadness, have a greater impact on heart rate than happiness or disgust (Levenson and Wagner, 1988). Therefore, heart rate is an indicator of the sum of challenges to an organism, as it is a sensitive parameter of both physical and psychological workload (Myrtek, 2004). In particular, additional heart rate (i.e. in addition to control situations) can be used as an indicator of emotional stress (Myrtek, 2004).

Heart rate is linearly correlated with workload over the range of 110 to 210 beats per minute for horses (Evans, 1977), until maximum heart rate, which normally ranges for different individuals between 212 and 240 beats per minute (Evans, 1977), is approached. Resting heart rate ranges between 25 and 60 beats per minute in horses (Clayton, 1991), and exercise training results in only slight (Kuwahara et al., 1999)if any, decrease in resting heart rate (Evans, 1977). Generally, resulting heart rate is nearly an additive combination of the respective heart rate changes elicited by a variety of stressors (Myrtek et al., 2005). Therefore, when all but one stressor is kept equal, differences in heart rate can be attributed to levels of the manipulated stressor. Rapid changes in heart rate are always induced by vagal stimulation (Goldsmith et al., 1993) and occur typically within $5 \mathrm{sec}$ (Hainsworth, 1995), but are short-lived. In contrast, regulation by the sympathetic nervous system usually takes up to $5 \mathrm{sec}$ for initial effects to take place and maximum responses are reached after 20 to $30 \mathrm{sec}$ (Malliani, 1995). Rising heart rates are predominantly the result 
of an increase in sympathetic activity (Hainsworth, 1995) but they may also result from a decrease in parasympathetic stimulation or simultaneous changes in both systems (von Borell et al., 2007).

Several studies have been carried out in cattle and horses, investigating the reliability of monitors for measuring HR relative to a standard ECG (Hopster and Blokhuis, 1994; van Oldruitenborgh-Oosterbaan, 1988) and results suggest that reasonably accurate measuring equipment is available. Nevertheless, it is of paramount importance to assess validity and correct function of individual equipment before commencement of data collection (cp. Pierard et al., 2015.; Górecka-Bruzda et al., 2012). Comparisons of stress-related cardiac activity should only be undertaken when similar behavioural activity is present. These requirements pose a considerable methodological problem to stress research as different treatments often induce different behavioural reactions (von Borell et al., 2007).

\subsubsection{Heart rate variability}

Heart rate variability describes variations of inter-beat intervals (Task Force of the European Society of Cardiology, 1996). In healthy subjects, intervals between consecutive heart beats are irregular. This irregularity is a result of rhythmic oscillation of the components that regulate cardiac activity in response to challenges and in the attempt to maintain cardiovascular homeostasis within the defined limits (Akselrod, 1995; Cerutti et al., 1995). In addition to mean heart rate, heart rate variability provides information about the sympathetic-parasympathetic autonomic balance (Stein et al., 1994; Task Force of the European Society of Cardiology, 1996). Therefore, many authors used heart rate variability to assess emotional reactivity. However, Myrtek (2004) argues that it is mainly an indicator of mental workload. The sinoatrial node, the primary pulse generator for contraction of the heart muscle, is under the control of the parasympathetic (vagal) and the sympathetic nervous system (Akselrod, 1995). Therefore, heart rate and heart rate variability is the result of interactions between heart-rate-reducing parasympathetic and heart-rate-increasing sympathetic stimulation (Hainsworth, 1995). Psychological states may have an impact on sympathovagal balance in the absence of any tangible changes in heart and/or respiration rates (Tiller et al., 1996). Therefore, heart rate variability is a particularly good indicator of psychophysiological stress (Cerutti et al., 1995). In horses, measurements of heart rate variability have been found to be lower, for example, during exposure to novel objects (Visser et al., 2002) or in more reactive individuals (Friedman and Thayer, 1998). Heart rate variability may therefore be a useful tool for assessing stress related to fear and anxiety in horses.

Controversy exists regarding the question of whether or not heart rate variability measurements provide valid information under exercising conditions, in particular when using non-ECG-based equipment. For 
example, one study demonstrated that under non-stationary conditions, there are significant deviations of heart rate variability recordings by Polar heart rate monitors as compared with ECG recordings (Parker et al., 2009). It is likely that this disagreement is due to loss of contact between electrodes, a risk that increases during ambulatory conditions (Parker et al., 2009). Furthermore, it has been hypothesised that because the equine ECG has a pronounced ' $\mathrm{t}$ '-wave, this may be mistaken for an R-peak by R-R detectors in these commercial systems (Parker et al, 2010), leading to misidentification of heart beats. However, other studies suggest that measurements up to moderate exercise intensities may yield valid information (Physick-Sheard et al., 2000) provided that signal detection is accurate. During increased workload due to exercise, vagal withdrawal is responsible for heart rate increases of up to 100-120 bpm, while further increases to maximal heart rate are the result of increased sympathetic drive (Kuwahara et al., 1996; Physick-Sheard et al., 2000). However, even when working at exercise intensities below 100-120 bpm, care should be taken when measurements taken from different exercise intensities are compared. Due to the close relationship between heart rate and heart rate variability, at the very least HRV parameters should be corrected for differences in heart rate / activity level when these factors cannot be controlled for (König von Borstel et al., 2011). Whether these measures are truly sufficient has yet to be proven.

A wide range of different parameters of heart rate variability are available. Table $1 a$ and $b$ give an overview of the heart rate variability parameters that have been assessed in horses, and the most frequently used parameters, which can be categorized into frequency and time domain parameters, are discussed below.

\subsubsection{Time domain parameters}

For time domain parameters the inter beat intervals (interval between two consecutive beats) is the basis for the measure. The parameter "root-mean square differences of successive beat-to-beat intervals" (RMSSD) is the primary time domain measure used to estimate the high frequency beat-tobeat variations that represent vagal regulatory activity (Von Borell et al., 2007). Another measure is the mean of the standard deviations for all beat-to-beat (RR) intervals (SDRR) (also termed the mean of the standard deviations for all normal-to-normal intervals (SDNN)). While RMSSD measures the variability derived from differences between adjacent inter beat intervals, the SDRR measures the variability derived from the inter-beat intervals directly. A number of additional time-domain parameters are available (see Task Force of the European Society of Cardiology, North American Society of Pacing and Electrophysiology, 1996 for an overview of the most established parameters), but so far they have rarely been used with horses, and some, such as the standard deviation of all beat-to-beat intervals in 
successive five-minute epochs (SDANN) are of limited value to studies investigating short-term effects as they provide estimates of the long-term components of HRV. Reduction in HRV parameters indicates a transition toward sympathetic control of cardiac activity (Task Force of the European Society of Cardiology, North American Society of Pacing and Electrophysiology, 1996). It has been recommended that for HRV detection a minimum of 5 min sampling time should be used and that the collected data are compared with a baseline value (pre-test, home environment situation). Furthermore, a minimum sampling frequency of $100 \mathrm{~Hz}$ (and considerably higher, i.e. optimally $250-500 \mathrm{Mz}$, if interpolation algorithms are not appropriate to lower sampling frequencies) should be met by the heart rate monitor to ensure that no R-wave peaks are missed in heart beat detection due to insufficient sampling frequencies (Task Force of the European Society of Cardiology, North American Society of Pacing and Electrophysiology, 1996).

Several studies have used time domain parameters to evaluate the response of horses to exposure to a novel object (König v. Borstel et al., 2011) or handling (e.g., Visser et al., 2002) and the effect of different training methods (van Breda, 2006; Christensen et al., 2014). These situations commonly induce a physiological state characterised by an increase in mean HR and a decrease in SDNN and RMSSD potentially representing increased levels of stress. Furthermore, time domain parameters have been used to underpin temperamental traits of horses. For example Thayer et al. (1997) found that more reactive horses had a reduced HRV. Therefore, time-domain measurements of HRV such as RMSSD and SDNN appear to be potentially useful indicators of stress, also in the context of equitation science, if applied correctly.

\subsubsection{Frequency domain parameters}

In the context of equitation science, events of short duration are commonly of interest to the researcher. For example, rides in horse shows and specific handling procedures commonly only last for a few minutes or less. With regard to heart rate variability, frequency rather than time domain parameters are considered to be better suited for short-term recordings (Task Force of the European Society of Cardiology, North American Society of Pacing and Electrophysiology, 1996). Frequency domain parameters assess the total or relative power of the different frequency bands. Frequency bands relevant for short-term recordings < 5 minutes include the, low (LF), and high frequency (HF) bands (Task Force of the European Society of Cardiology, North American Society of Pacing and Electrophysiology, 1996). The HF component is a marker for vagal activity and is closely linked to respiration (Task Force of the European Society of Cardiology, 
North American Society of Pacing and Electrophysiology, 1996), while LF is sometime considered to reflect mainly sympathetic (Cerutti et al., 1995) activity, but usually is considered to be the combined effects of parasympathetic and sympathetic modulation (Stein et al., 1994). Therefore, LF/HF is considered to be an index of the cardiac sympathovagal balance, and is in addition to normalised LF and HF commonly used to assess stress. Based on the direct link to respiration rate, species-specific band-widths are required, and von Borell et al. (2007) recommend limits for the HF band of $0.13-0.26 \mathrm{~Hz}$ in adult horses and $0.25-0.33 \mathrm{~Hz}$ in foals. However, using pharmacological manipulation, Kuwahara et al. (1996) estimated the appropriate band-widths for horses to be 0.01-0.07 (LF) and 0.07-0.6 (HF), and the same or similar band- widths (LF: same, HF: 0.07-0.5), were also adopted by Physick-Sheard et al. (2000). However, Rietmann et al. (2004b) suggest different bands, ranging from 0.05-0.15 (LF) and 0.15-05 (HF). Some researchers also suggest the use of human frequency bands as appropriate for use with horses (Gehrke et al., 2011) while others do not report the band widths used, probably because they corresponded to the human frequency bands which are usually the default settings in popular software used for heart rate variability analysis. Clearly, the latter approach lacks scientific justification, and should not be adopted for future studies. Possibly, different groups of horses differ with regard to the band widths, and further validation studies may be required to determine the most appropriate band widths for a specific set of horses in a study. In future, as a minimum level it is recommended to use band widths as suggested by one of the above studies, depending on which experimental setting and group of horses from the above studies resembles the sample for the planned study most.

Regardless of the lack of agreement over bandwidths, due to the nature of the different cycle lengths influencing heart rate variability, minimum recording time for frequency domain parameters should normally not be shorter than 1 minute (HF components) or 2 minutes (LF components), and for standardisation purposes, segments of 5 minutes are suggested, unless otherwise dictated by the experimental design (Task Force of the European Society of Cardiology, North American Society of Pacing and Electrophysiology, 1996).

\subsection{Endocrine measures of stress}

\subsubsection{Cortisol}

Although blood or plasma levels of endocrinological indicators of stress can potentially provide accurate measurements of stress, blood sampling in itself can be perceived as a stressor and this may affect results. Catheterizing the animals can be a solution in some cases to reduce the stress at the time of blood 
sampling. However, the procedure is costly, time consuming, and invasive and thus under many circumstances is not feasible, in addition to potentially being subject to legislative restriction. On the other hand, non-invasive measurements such as cortisol in saliva, urine, faeces or hair are variable in the extent to which they provide an accurate assessment of states of stress. When physiological measures are used to assess stress associated with equitation it is often short-term (acute) stress responses that are of interest, and in these cases meaningful measures can only be obtained from plasma or saliva. If the longerterm impact of training procedure, competition duration or ridden role is to be assessed then this would be classed as a more chronic stress response and measures of cortisol from urine (Popot et al., 1997), faeces or hair may then be of value. However the interpretation of changes in cortisol concentration and indeed the implications of differing baseline cortisol levels remain unclear. Colborn et al. (1991) showed that cortisol is a universal indicator of both negative and positive stress in horses, as increases in stallions' cortisol levels in response to sexual stimulation, acute physical exercise, restraint via a twitch and adrenaline administration are similar. However, a more recent study did not confirm the earlier findings of raised cortisol levels in response to semen collection in stallions (Pasing et al., 2013), potentially suggesting that e.g., the way of handling stallions during semen collection may also affect results. Moreover, in some individuals some stress responses may not result in an increase in cortisol concentrations, as highlighted in primates by Honess and Marin (2006). Indeed when chronic stress has resulted in symptoms of 'behavioural despair' baseline cortisol levels have been found to be relatively low (Fureix et al., 2012).

Within equitation science both plasma and salivary cortisol concentrations have been used as measures of the effect of physical exercise on the horse (for example, Medica et al., 2011; Gordon et al., 2007) and when applied to evaluating stress per se the interpretation of such measures requires careful consideration. The link between fitness, exercise type, physical and psychological stress on cortisol levels, in terms of both baseline levels and the response to activation of the HPA axis, and health and well-being has yet to be fully determined. The complexity of evaluating the implications of differing levels of cortisol and changes therein in human athletes is discussed at length by Gerber et al. (2012) and similar considerations apply when using this parameter as a measure of stress in the equine athlete. However, plasma and salivary cortisol levels have been used as a measure of stress in relation to a number of different variables, including training, level of experience of both horse and rider and competition. The distinction between physical and psychological stress is often unclear. Rivera et al. (2002) investigated the effect of housing / management type on the behavioural and physiological responses of horses to initial training. Throughout the 28 day training period baseline plasma cortisol levels increased significantly, with 
higher increases being associated with longer training bouts. An unexplained anomaly did occur on day 21 when baseline cortisol level dropped for all horses to levels comparable with the pre-training baseline level. Although differences in behaviour and training between stalled and pastured horses were found, with the latter showing fewer signs of stress, no differences in cortisol levels were found. Stage of training and duration of training bouts affected cortisol levels but housing did not (Rivera et al., 2002).

The effect of horse and rider experience on salivary cortisol levels when jumping a course of jumps was assessed by Ille et al. (2013). Measures were taken at $-30,-15,0,+15,+30$ and +60 minutes, with the collection at 0 being straight after the jumping round. A ridden warm-up session of 11 minutes was carried out before the jumping trial and peak cortisol levels were recorded after the jumping. Cortisol level in the horse was not affected by the experience of either the horse or rider, but by exercise (Ille et al., 2013). Similarly when the comparative effect of either rehearsal or public performance of high-level classical dressage movements (airs above the ground) on salivary cortisol levels were measured, no difference was found (von Lewinski et al., 2013). There was a significant effect of the ridden work in raising cortisol levels in both scenarios, but no association with what could be assumed to be the more stressful experience of public performance (von Lewinski et al., 2013).

Within equitation science there has been much debate surrounding the use of dorso-ventral flexion of the head and neck during training, in particular in relation to dressage. Consequently the impact of this training on stress parameters, including plasma and salivary cortisol levels, has been investigated. It has been suggested that hyperflexion of head, neck and poll can result in increased plasma cortisol levels when compared with working the horse in a looser frame (Christensen et al., 2014) or in a way that results in the nose line being slightly in front of, or perpendicular to, the vertical with the poll being the highest point (defined as the 'working' head-neck position: Zebisch et al., 2014). However, in the latter study, all horses were worked initially in the 'working' position, followed by the hyperflexed position. Blood was sampled for cortisol analysis pre-trial in the stall, then immediately after each stage (working then hyperflexed). Consequently the higher level of cortisol found after the second trial could well have been the result of the increased time that they had been worked for, as also found by Rivera et al. (2002). Zebisch et al. (2014) note that they did not use a cross-over design and that the horses were not trained in hyperflexion, but do conclude that this cortisol increase relates to the general discomfort of the position. An association between head and neck position (although not hyperflexion) and salivary cortisol levels was also found by Hall et al. (2014). Increases in salivary cortisol positively correlated with the duration of low (as opposed to neutral or high) head carriage. In this case the authors concluded that this low head position may be 
associated with the horse 'working harder' and could be interpreted as a sign of greater physical exertion, so potentially more physically stressful.

The extent to which conclusions can be drawn regarding the mental / psychological stress experienced by horses on the basis of either baseline or HPA activated plasma or salivary cortisol levels is still under review. To date, the implications are that it is activity, arousal and physical stress that result in raised cortisol levels in the short term. Ridden work and training methods that cause pain or discomfort to the horse may or may not result in a raised cortisol level. When behavioural and physiological measures were compared in horses suffering from laminitis, plasma cortisol levels were found to be poorly associated with other parameters (Rietmann et al., 2004a). Chronic inflammation in the horse was found to be associated with depressed baseline plasma cortisol levels (Mills et al., 1997) but increased levels of faecal glucocorticoid metabolites were found in horses that had previously undergone a painful experience (colic or castration) (Merl et al., 2000). Increases in salivary cortisol were found in horses undergoing a potentially aversive procedure (clipping) but this increase did not differ between those horses that exhibited avoidance/anxiety related behaviour and those that did not (Yarnell et al., 2013). Here it is likely that clipping causes an alerting response, but the valence of that response is not clear. Positive correlations between baseline (resting) cortisol levels and age have been found (Hall et al., 2014) and as has been noted above factors such as stage of training and fitness will affect baseline cortisol levels and HPA response. Diurnal rhythms in baseline cortisol levels have been demonstrated in some but not all studies that aim to assess circadian variability (Irvine and Alexander, 1994). Despite these confounding factors, cortisol responses and underlying baseline levels can contribute to the assessment of stress in the ridden horse. Changes in cortisol level are undoubtedly a measure of physical stress and workload, indicative of activation level and affected by previous experience. However, there is no conclusive evidence that cortisol levels are indicative of mental state or that they can be used as an objective means of interpreting ridden horse behaviour.

Despite these reservations, the sampling of cortisol as a means of providing physiological evidence of stress is considered to be valuable. To ensure that the measures taken are meaningful and representative of the hormonal response to stress, whether this be physical or psychological, samples need to be taken prior to test procedures and subsequently repeated until at least an hour post-procedure. Baseline / resting cortisol levels are required to allow for increases, rather than actual levels to be compared. The HPA activation that results in increases in cortisol level results in a time delay of approximately 15 minutes between stressor and any resultant change. Similarly, cortisol levels alter over time and may take an hour or more to return to baseline levels. The profile associated with these changes in relation to the timing of 
the stressor or trial provide valuable information regarding the individual response. See Ille et al. (2013) and Hall et al. (2014) for examples of cortisol response profiling.

\subsubsection{Other endocrine or humoral parameters}

Other stress-indicators that have been used in horses include (see also table 1) plasma or blood lactate levels (Powell et al., 2008; Fazio et al., 2013; Munsters et al., 2013), plasma ascorbic acid (Baucus et al., 1990), prolactin (Colborn et al., 1991),iodothyronine (Medica et al., 2011), oestradial-17ß (Medica et al., 2011), serum creatin kinase activity (Powell et al., 2008), packed cell volume (Sloet van OldruitenborghOosterbaan et al., 2006), ACTH (Ferlazzo et al., 2012; Fazio et al., 2013) and plasma $\beta$-endorphin (McCarthy et al., 1993; Gillham et al., 1994; McGreevy and Nicol, 1998; Niinistö et al., 2010; Ferlazzo et al., 2012) as well as various other parameters for example, related to blood chemistry (e.g., De Rantere et al., 2007) and immune function (Malinowski et al., 2006). However, all these parameters are predominantly linked to physiological workload or other physiological processes in the body, and it is questionable to what extent, if any, these parameters can serve to detect psychological stress. Nevertheless, of the above parameters, $\beta$-endorphin may be of particular relevance to psychological stress, due to its analgesic effects (Foley et al., 1979). Future research should focus on potential feedback mechanisms between exerciseinduced endogenous opioid release and the valence horses assign to these exercise bouts.

When controlling for confounding effects, plasma concentrations of adrenaline and noradrenaline are useful as a measure of acute stress such as fear. In mammals, adrenaline results in increased heart rate and force of contraction of the heart and dilatation of arteries to enhance blood flow through skeletal muscles and bronchioles (Myrtek, 2004). Noradrenaline causes constriction of veins and arteries particularly in the skin and the digestive system (Myrtek, 2004). This leads to reduced blood supply and thus temporally reduced functioning of these organs, with the purpose of redirecting blood flow to the muscles and other organs necessary for a flight reaction. However, adrenaline has a short half-life of only a few minutes, making this substance an impractical parameter for studies under field conditions.

\subsection{Body/eye temperature}

The changes in circulation associated with hormonal activity, as described above, have been used as a means of assessing the stress response in a number of different species. Changes in surface temperature are associated with changes in underlying blood flow and these can be measured using thermal imaging 
cameras. Acute stress responses have been associated with species-specific patterns of vasoconstriction and dilation that provide a means of quantifying such responses. In particular, changes in facial temperature in humans have been associated with fear responses, typically resulting in instantaneous periorbital warming and cheek cooling (Levine et al., 2001). The instantaneous warming around the eyes has been associated with the fright/flight response that relates to activation of the sympathetic-adrenal medulla axis (Pavlidis et al., 2002). Decreases in nasal temperature in response to threatening situations have been found to be associated with facial expressions of negative emotion in rhesus monkeys (Macaca mulatta) (Nakayama et al. 2005). Stressful procedures in dairy cows were shown to produce HPA-activated increases in cortisol alongside SAM-activated increases in eye temperature (Stewart et al., 2007). Although both of these measures detected stress responses in the cows, the underlying mechanism by which these changes occurred differed. Although stimulation of the HPA axis resulted in increases in cortisol, it was concluded that a cognitive rather than purely hormonal component was required to cause the increase in eye temperature (Stewart et al., 2007).

Monitoring changes in eye temperature has been applied to assessing the response of horses to potentially stressful situations. Yarnell et al. (2013) found significant increases in eye temperature that correlated with increases in salivary cortisol in horses during the potentially aversive procedure of clipping. Eye temperature increased throughout the procedure, peaking at the end of the ten minute period of clipping and only dropped after the procedure was ceased (Yarnell et al., 2013) These authors((Yarnell et al., 2013) did not find any relationship between the physiological parameters and behaviour. However, when the behaviour of horses undergoing a saliva sampling procedure was scored on the basis of descriptors indicative of anxiety, a positive correlation with eye temperature increases was found (Hall et al., 2014). The potential discomfort associated with tight, jaw-clamping crank nosebands was shown by McGreevy et al. (2012) to result in increases in eye temperature. Undoubtedly changes in temperature in the area surrounding the eye of the horse appear to be indicative of alerting, anxiety and possible discomfort.

To date, no effect of exercise per se on eye temperature has been found and consequently this measure may offer a means of evaluating mental stress without being confounded by the effect of exercise and physical stress. Hall et al. (2014) found increased eye temperature related to head carriage associated with the nasal plane being behind the vertical. Valera et al. (2012) found increases in eye temperature that related to competition stress during show jumping and concluded that infrared thermography (IRT) was a rapid, non-invasive measure that could be applied in a range of situations. When horses were lunged in a training device (Pessoa) they were found to have significantly higher eye temperatures than when lunged without (Hall et al., 2011). Increases in core temperature were also associated with lunging with the Pessoa 
(Hall et al., 2011), which supports the conclusion that this device increases the stress associated with this exercise. Oka and Hori (2001) investigated the association between psychological stress-induced increases in core temperature. They concluded that these increases did not relate to increases in locomotor activity, but the factors affecting temperature changes require further investigation. Evidence so far suggests that changes in eye and core temperature in horses are related (Johnson et al., 2011), and that both these measures may contribute to assessing stress in ridden horses.

To ensure that measures taken using IRT are valid and accurate there are a number of factors that need to be controlled for. These include ambient conditions, coat colour, surface moisture and distance from which the measures are taken. A review of the role of thermography in the management of equine lameness by Eddy et al. (2001) provides an overview of factors that can affect measures using IRT. The accuracy of the thermal cameras now available varies considerably and validation against other temperature-based measures is recommended. Further details of the use of IRT as a measure of stress in the horse can be found in Pierard et al. (2015).

\subsection{Behavioural indicators of stress}

Behaviour is by definition plastic and provides the horse with the flexibility to respond as deemed appropriate to challenging situations. Therefore, behavioural responses to stress may also be more varied than the physiological responses. More so than with physiological parameters, behaviour may give an indication of the nature of the stressor, e.g., if plain exercise or additionally pain, anxiety or fear are involved.

\subsubsection{Behavioural indicators of stress due to fear or anxiety}

Horses most commonly flee in response to fear (Grzimek, 1944), but may resort to fight if there is no escape (Voith, 1979). If both fight and flight are prevented animals may show conflict behaviour and/or if the fear response is more chronic in nature, animals may develop abnormal behaviour such as stereotypies (Wiepkema and Schouten, 1992). When states of fear, as induced by certain handling or training procedures for example, are of interest rather than instantaneous flight reactions, the fear potentiated startle test (Clark et al., 2004) may provide useful information on an animal's level of fear or anxiety.

The startle response is a reflex to abrupt and intense stimulation that shows a stereotyped reaction similar across species. It consists of a rapid sequential muscle contraction that leads to the forward thrusting of the head and a descending flexor wave reaction, extending through the trunk and the knees (Landis and 
Hunt, 1939). The amplitude of the startle reflex is variable and depends on the internal state of the organism (Grillon and Baas, 2003). For example, negative emotions such as anxiety or fear lead to increased startle responses (Brown et al., 1951). Thus, fear-potentiated startle tests can be used to assess the amount of fear a stimulus elicits by measuring its effect on the startle response (e.g., Davis et al., 1987), and the combination of startle and fear reaction in response to suddenly presented stimuli are commonly used in unmounted horses to assess fear (Anderson et al., 1999; Visser et al., 2001; Lansade et al., 2004; Christensen et al., 2006; Górecka et al., 2007). In ridden horses, an anxiety-potentiated startle test was used to assess the psychological impact of training in a hyperflexed head and neck posture on horses (von Borstel et al., 2009). Horses tended to show stronger startle reactions when ridden in hyperflexed rather than regularly flexed head and neck postures (von Borstel et al., 2009), suggesting that this training method resulted in heightened states of anxiety or other negative experiences such as pain in the horses.

\subsubsection{Behavioural indicators of stress due to pain and/or conflict with the rider's aids}

A "horse grimace scale" has been used to quantify pain in horses (Dalla Costa et al., 2014), although this specific method has yet to be applied to and validated for the ridden horse. Potentially, facial expressions of pain are not always clearly visible in the ridden horse. For example, pieces of tack may cover parts of the face and indeed nosebands are specifically designed to inhibit mouth-opening (König von Borstel and McGreevy, 2014). In addition, stress-induced analgesia (Butler and Finn, 2009) may be present in horses during stressful events such as horse shows or races as suggested by Wagner ( 2010), and therefore, horses' reactions to stimuli that would normally elicit pain may be altered under these conditions. A number of studies assessed horses' postures such as head and/or ear posture as a potential indicators of their emotional states (von Borstel, 2008a; Heleski et al., 2009; von Borstel et al., 2009). When these postures are assessed, often duration is measured (Hall et al., 2014), although instantaneous samples may also be used (von Borstel and König, 2008; von Borstel et al., 2011). The presence of eye-white has also been recorded (von Borstel et al., 2009). However, unlike in cows (Sandem et al., 2004), in that study (von Borstel at al., 2009) the visibility of eye-white might have been related to the horses' attempts to see when being ridden with their head and neck in a hyperflexed position.

To date, investigations of pain and discomfort in the ridden horse most commonly focused on escape and avoidance behaviour, commonly also referred to as conflict behaviour, i.e. behaviour indicative of conflict between the horse's interests and the rider's aids. These behaviour patterns include a variety of unwanted changes in locomotory behaviour such as bolting, rushing, running away, jogging, jibbing, napping, baulking, refusing, shying, spinning, freezing, bucking, rearing and bridle lameness (see McGreevy and McLean, (2010) for detailed explanations and functional interpretations) as well as behaviour patterns 
directly related to the rider's interaction with the horse such as head-tossing or reefing the reins (von Borstel et al., 2009; von Borstel et al., 2011; König von Borstel and Glißman, 2014), mouth-opening and tail-swishing (VanderHorst et al., 2013; Kienapfel et al., 2014; Górecka-Bruzda et al., 2015). Defaecation as a result of the effects the activation of the HPA-axis has on the digestive system, may also be observed (e.g. Rietmann et al., 2004b). In a few instances with equitation-related contexts subjective scores have been used to evaluate behaviour (Zebisch et al., 2014) or durations of behaviour patterns have been measured (e.g., Hall et al., 2014). However, given greater technical effort required to assess durations rather than frequencies of behaviours and given the multitude of studies assessing frequencies of conflict behaviour (see Table 1) and thereby detecting significant differences between treatments, it is suggested that the assessment of frequencies of conflict behaviour is a particularly useful and practical means of assessing stress in the ridden or exercising horse. Nevertheless it should be noted that the use of an appropriate ethogram with detailed descriptions of behaviour patterns is paramount. Ethograms, if provided at all, usually leave considerable room for interpretation regarding the cut-off point at which one unit of a behaviour pattern is considered to be completed versus not be completed, i.e. not counted as an additional unit. For a detailed review of the ridden horse ethogram, see Hall and Heleski (this issue). In the following, only a brief overview of studies investigating potentially stress-inducing situations is given. Equestrian activities that have been investigated with regard to the level of psychological stress they impose on the horse, as assessed based on the frequency of conflict behaviour, include for example:

- Different degrees of poll flexion (the frequency of conflict behaviour increases, when horses are trained in more rather than less flexed head and neck postures; (von Borstel et al., 2009; Kienapfel, 2011; Christensen et al., 2014; Kienapfel et al., 2014; Smiet et al., 2014)

- Different ways of rider behaviour or interaction with the horse (von Borstel, 2008; Egenvall et al., 2012)

- Different types of riders / riding sessions (no significant differences in frequencies of conflict behaviour were seen in horses ridden either by recreational riders, physiologically handicapped riders, psychologically handicapped riders or special education children, but higher frequencies of conflict behaviour were seen when the horses were ridden by at-risk children (Kaiser et al., 2006)

- Different types of tack such as bitted versus bitless bridles (Quick and Warren-Smith, 2009) or martingales (Heleski et al., 2009)

However, it is important to note, that not necessarily all stress-inducing situations are expected to lead to increased levels of conflict behaviour. Under certain circumstances, if training methods are aversive with 
limited possibilities for the horse to control the situation, learned helplessness may be induced (Hall et al., 2008). If this is the case, horses may be apparently compliant with the trainer's requests, even though the horse is showing little more than apathy. Furthermore, it has been suggested that some horses may suffer from depression-like conditions (Fureix et al., 2012; Fureix et al., 2015), which may be related to learned helplessness. As such a state bears the potential for serious harm to the horses' welfare, future studies should carefully consider this aspect. Therefore, increased levels of conflict behaviour appear to be a sensitive parameter for stress in horses, but the reversed conclusion that the absence of conflict behaviour is indicative of good welfare is not valid.

\subsubsection{Additional behavioural measurements related to stress}

Apart durations or frequencies of behaviour states or patterns, subjective behaviours scores (Munsters et al., 2012; Zebisch et al., 2014) or other qualitative forms of behaviour assessment (König von Borstel et al., 2011; Fleming et al., 2013) are another means of quantifying behaviour. These scores often are useful in revealing treatment differences, but it is noteworthy that, perhaps in the interest of brevity of scientific articles, descriptions of individual scores are often not detailed enough to allow external researchers to exactly reproduce the used methods.

Particularly informative behavioural measures are provided by motivational and preference tests. Perhaps due to the comparably complex nature of the suitable experimental designs, motivational and preference tests have to date not been used frequently in equitation science. However, preference tests have been used successfully to study horses' desire to work in general (Lee et al., 2011; König von Borstel and Keil, 2012) or under certain conditions (von Borstel et al., 2009; Górecka-Bruzda et al., 2011), and links between non-preferred treatments and changes in levels of other potential stress parameters may serve to validate these parameters as indicators of psychological stress. With regard to equitation science highly relevant information was also provided by a study on horses' voluntary acceptance of rein tension (Christensen et al., 2011).

\subsection{Comparison of different parameters for assessment of short-term stress}

Links between the different stress parameters both within and across studies are generally incomplete. For example Young et al. (2012) report a significant correlation between behavioural scores and peak salivary cortisol concentration measured during the husbandry procedures, confirming that the final behavioural score scale was a reflection of both behavioural and physiological stress. However, with a correlation coefficient of $r s=0.54(P=0.02, N=18)$, it is apparent, that the relationship between the two parameters is not a particularly close one. However, as indicated above, behaviour is by definition plastic, 
and therefore it cannot be expected to detect perfect links either between physiological and behavioural parameters or between different behavioural parameters. Table 3 provides an overview of the agreement between different parameters when used simultaneously to test a difference in stress-related treatments. For physiological parameters, the largest proportion of agreement (i.e. both parameters simultaneously indicated either higher, non-significantly different or lower stress compared to a control treatment) was found for cardiovascular parameters, while generally limited agreement was found for both saliva and blood cortisol and cardiovascular parameters. This comparably large proportion of disagreement may be explained by the different physiological pathways involved with the different parameters (see chapter 1.1). Behavioural parameters generally showed good agreement with all physiological parameters, but it should be noted, that often a large number of different behavioural parameters were recorded, and only the results specifically reported in the studies were included in this comparison. Notably, there is only one study that reported contrasting results for two physiological parameters (RMSSD and HR) such that one parameter indicated higher stress with treatment $A$, while the other parameter indicated lower stress with treatment A (Table 3). However, likely publication bias is present (cp. Chan and Altman, 2005), such that contrasting and unexplainable results may not have been reported. Thus the proportions of agreement between parameters from the present overview is likely to be over-estimated. Overall, this comparison (Table 3) highlights the importance for equitation researchers to inform themselves about the exact responses they intend to measure. When overall stress-load is of interest, a combination of different parameters appears to be the most useful approach. Given their usefulness and relative simplicity in recording, these parameters should always include behavioural measurements.

Table 3. Proportion of agreement (above diagonal) and disagreement (below diagonal; grey shading) between different parameters of various studies attempting to assess short-term stress in exercising horses. (Figures above diagonal represent the number of treatment comparisons out of the total number of inspected treatment comparisons (from studies listed in Table 1) the two respective parameters simultaneously yield indication of higher, lower, or non-significantly altered stress levels. Significant correlations between two parameters were likewise counted as agreement. Figures below the diagonal represent the number of comparisons out of the total number of comparisons for which the two respective parameters yield contrasting results (one parameter indicative of higher, the other of lower stress for a particular treatment; $\mathrm{HR}=$ heart rate; RMSSD = root-mean square differences of successive beat-to-beat intervals; LF/HF = ratio of low to high frequency bands).

\begin{tabular}{|c|c|c|c|c|c|c|c|}
\hline & HR & RMSSD & LF/HF & $\begin{array}{l}\text { Saliva } \\
\text { cortisol }\end{array}$ & $\begin{array}{l}\text { Blood } \\
\text { cortisol }\end{array}$ & $\begin{array}{l}\text { Eye } \\
\text { temperature }\end{array}$ & Behaviour \\
\hline HR & & $7 / 9$ & $3 / 3$ & $1 / 2$ & $1 / 4$ & & $7 / 12$ \\
\hline RMSSD & $1 / 9$ & & $1 / 1$ & $0 / 1$ & & & $0 / 1$ \\
\hline LF/HF & $0 / 3$ & $0 / 1$ & & $0 / 1$ & $0 / 1$ & & $4 / 6$ \\
\hline
\end{tabular}




\begin{tabular}{|l|l|l|l|l|l|l|l|}
\hline $\begin{array}{l}\text { Saliva } \\
\text { cortisol }\end{array}$ & $0 / 2$ & $0 / 1$ & $0 / 1$ & & $2 / 3$ & $1 / 3$ & $2 / 3$ \\
\hline $\begin{array}{l}\text { Blood } \\
\text { cortisol }\end{array}$ & $0 / 4$ & & $0 / 1$ & $0 / 3$ & & & $2 / 2$ \\
\hline $\begin{array}{l}\text { Eye } \\
\text { temperature }\end{array}$ & & & & $0 / 3$ & & & $1 / 1$ \\
\hline Behaviour & $0 / 12$ & $0 / 1$ & $0 / 6$ & $0 / 3$ & $0 / 2$ & $0 / 1$ & \\
\hline
\end{tabular}

\section{Indicators of long-term stress in equitation}

Parameters such as stereotypic behaviour, learned helplessness, altered metabolism or supressed immune function (Robson et al., 2003) may have the potential to provide information on the long-term effects of e.g. training techniques and riding/working styles. Since long-term stress may result in stereotypies, this is effectively one of the most widely used behavioural responses to monitor chronic stress. Stereotypies have been studied extensively in horses (e.g. Hothersall and Casey, 2012; Cooper and Mason, 1998; Henderson, 2007). The presence of stereotypies has been used as an indicator of poor welfare (Broom, 1986). However, the development of stereotypies takes time and goes through different stages which inevitably makes clear why stereotypies cannot be used to assess acute stress. Moreover, since horses may undergo different housing regimes, training methods, change of owner and other external factors, the causal factor of the development of a stereotypy may sometimes be hard to distinguish. Equine epidemiological studies have shown relationships between different management related factors such as equestrian discipline. McGreevy et al. (1995) showed that dressage horses displayed a higher percentage of abnormal behaviours, whilst endurance horses, being housed/stabled less displayed the lowest percentage of abnormal behaviour. Experimental studies have also demonstrated a relationship between feeding or housing practices and the development of stereotypies. Visser et al. (2008) proved the relationship between housing conditions (social isolation versus pair housed) and the development of locomotor stereotypies in young horses.

While saliva or blood (plasma) cortisol levels are being used to assess short term stress, a promising parameter to assess long-terms stress is the ACTH-axis response to a CHF challenge. Visser et al. (2008) showed that the chronically stressed horses housed individually and in isolation responded with a reduced plasma cortisol response on the corticotropin releasing factor challenge compared to their counterparts who were housed in pairs. It was hypothesised that a similar mechanisms to depression is responsible for this result. Moreover, it has been suggested that a depression in adrenocortical reactivity to exogenous ACTH in socially isolated animals is caused by a desensitisation of the hypothalamic-pituitary-adrenal axis (HPA axis) in response to stress induced rises in ACTH and cortisol (Ladewig and Smidt, 1989). Similar 
results were obtained for socially isolated bulls and calves (Ladewig and Schmidt, 1989; Van Reenen et al., 2000). Furthermore, measurements of faecal cortisol levels may be a valid and non-invasive means of assessing chronic stress in horses (Palme, 2015). Hair cortisol levels have likewise been used to assess longterm stress in horses (Medill et al., 2015), but results may be biased due to temporal changes in hair growth as well as possible effects of local cortisol production in the hair follicle (Ito et al., 2005). Furthermore, it is unclear to what extent hair cortisol levels reflect total and free cortisol (Ito et al., 2005). Nevertheless, in line with what can be hypothesized, Medill et al. (2015) detected higher hair cortisol levels e.g., in lactating rather than non-lactating female feral horse, and in horses of poorer rather than better body condition. Therefore, hair cortisol levels might be promising approach for future studies to compare overall long-term stress, e.g. of horses undergoing different training regimens.

Due to the effects of long-term exposure to higher levels of corticosteroids on the immune system, measures of immune function (Malinowski et al., 2006) may also provide information on long-term stress, if other factors such as disease can be ruled out.

\section{Conclusions}

Heart rate, heart rate variability and cortisol levels along with behavioural parameters have frequently been used to assess short-term psychological stress in the ridden horse. However, an inherent and inadequately addressed problem with research in equitation science is the confounding of experimental treatments with horses' activity levels, such that the physical workload differs between treatments of a study. Physiological stress parameters may solely reflect an individual's arousal or activity level, but not necessarily provide information on the perceived valence of a situation. Exceptions are some heart rate variability parameters which provide information of the relative contributions of sympathetic and parasympathetic nervous systems, thereby providing information on how a situation is perceived by the horse. However, the effect of exercise level remains a problem with these parameters, and at any rate, reliable information can only be obtained at moderate exercise levels. A relatively novel, and promising approach to assess psychological stress also in exercising horses is the measurement of eye temperature via infrared thermography. Common to all physiological parameters is that complete compliance with rules for correct sampling and analysis (see Table 2 for a summary) is rarely achieved, despite being imperative for obtaining valid measurements. Given the high potential for measurement and sampling errors as well as erroneous interpretation with physiological parameters, it is suggested that behavioural rather than 
physiological parameters may currently be more robust and valid indicators of stress for use in equitation science.

\section{References}

Akselrod, S., 1995. Components of heart rate variability: basic studies, in: Malik, M., Camm, A.J., Armonk, N.Y. (Eds.), Heart Rate Variability, Futura, pp. 147-164.

Anderson, M.K., Friend, T.H., Evans, J.W., Bushong, D.M., 1999. Behavioral assessment of horses in therapeutic riding programs. Applied Animal Behaviour Science 63, 11-24.

Baucus, K.L., Squires, E.L., Ralston, S.L., McKinnon, A.O., Nett, T.M., 1990. Effect of transportation on the estrous cycle and concentrations of hormones in mares. Journal of animal science 68, 419-426.

Becker -Birck, M., Schmidt, A., Wulf, M., Aurich, J., von der Wense, A., Möstl, E., Berz, R., Aurich, C. 2013 Cortisol, heart rate and heart rate variability, and superficial body temperature, in horses lunged either with hyperflexion of the neck or with an extended head and neck posture. Journal of Animal Physiology and Animal Nutrition 97, 322-330.

Broom, D. M. (1991). Animal welfare: concepts and measurement. Journal Of Animal Science, 69(10), 4167-4175.

Broom, D. M. (1986). Indicators of poor welfare. Britisch Veterinary Journal, 142, 524-526.

Brown, J.S., Kalish, H.I., Farber, I.E., 1951. Conditioned fear as revealed by magnitude of startle response to an auditory stimulus. Journal of Experimental Psychology 41, 317-328.

Butler, R.K., Finn, D.P., 2009. Stress-induced analgesia. Progress in neurobiology 88, 184-202.

Cannon, W.B., 1953. Bodily changes in pain, hunger, fear and rage: an account of recent researches in the function of emotional excitement. Boston, USA.

Cerutti, S., Bianchi, A.M., Mainardi, L.T., 1995. Spectral analysis of the heart rate variability signal, in: Malik, M., Camm, A.J., Armonk, N.Y. (Eds.), Futura, pp. 63-74.

Chan, A.-W., Altman, D.G., 2005. Identifying oucome reporting bias in randomised trials on PubMed: review of publications and survey of authors. BMJ 330, 753

Chaya, L., Cowan, E., McGuire, B., 2006. A note on the relationship between time spent in turnout and behaviour during turnout in horses (Equus caballus). Applied Animal Behaviour Science 98, 155160.

Christensen, J.W., Beekmans, M., van Dalum, M., VanDierendonck, M., 2014. Effects of hyperflexion on acute stress responses in ridden dressage horses. Physiology \& Behavior 128, 39-45.

Christensen, J.W., Rundgren, M., Olsson, K., 2006. Training methods for horses: habituation to a frightening stimulus. Equine Veterinary Journal 38, 439-443.

Christensen, J.W., Zharkikh, T.L., Antoine, A., Malmkvist, J., 2011. Rein tension acceptance in young horses in a voluntary test situation. Equine Veterinary Journal 43, 223-228.

Christensen, J. W. (2013). Object habituation in horses: The effect of voluntary versus negatively reinforced approach to frightening stimuli. Equine Veterinary Journal, 45(3), 298-301. 
Clark, M.S., Vincow, E.S., Sexton, T.J., Neumaier, J.F., 2004. Increased expression of 5-HT1B receptor in dorsal raphe nucleus decreases fear-potentiated startle in a stress dependent manner. Brain Research 1007, 86-97.

Clayton, H.M., 1991. Conditioning Sport Horses. Sport Horse Publications, Saskatoon, Saskatchewan, Canada.

Colborn, D. R., Thompson, D. L., Roth, T. L., Capehart, J. S., \& White, K. L. (1991). Responses of cortisol and prolactin to sexual excitement and stress in stallions and geldings. Journal Of Animal Science, 69(6), 2556-2562.

Cooper, J.J., Mason, G.J., 1998. The identification of abnormal behaviour and behavioural problems in stabled horses and their relation to horse welfare: a comparative review. Equine Vet J Suppl 27, 5-9.

Covalesky, M. E., Russoniello, C. R., \& Malinowski, K. (1992). Effects of show-jumping performance stress on plasma-cortisol and lactate concentrations and heart-rate and behavior in horses. Journal Of Equine Veterinary Science, 12(4), 244-251.

Cregier, S.E., 1982. Reducing equine hauling stress: A review. Journal of Equine Veterinary Science 2, 186-198.

Dalla Costa, E., Minero, M., Lebelt, D., Stucke, D., Canali, E., Leach, M.C., 2014. Development of the Horse Grimace Scale (HGS) as a Pain Assessment Tool in Horses Undergoing Routine Castration. PLoS ONE 9, e92281.

Davis, M., Hitchcock, J.M., Rosen, J.B., 1987. Anxiety and the Amygdala - Pharmacological and Anatomical Analysis of the Fear-Potentiated Startle Paradigm. Psychology of Learning and Motivation-Advances in Research and Theory 21, 263-305.

Dawkins, M. S. (2003). Behaviour as a tool in the assessment of animal welfare. Zoology, 106(4), 383-387.

De Rantere, D., Schauvliege, S., ÖDberg, F.O., Deprez, P., Gasthuys, F., 2007. Poll-flexion does not induce hypoxia in unridden ponies while trotting. Proceedings of the International Society for Equitation Science 12.

Doherty, O., Booth, M., Cuddeford, D., Waran, N., \& Salthouse, C. (1997). Study of the heart rate and energy expenditure of ponies during transport. Vet Rec., 141(23), 589-592.

Eddy, A.L., Van Hoogmoed, L.M., Snyder, J.R. 2001. The role of thermography in the management of equine lameness. The Veterinary Journal. 162, 172-181.

Egenvall, A., Eisersiö, M., Roepstorff, L., 2012. Pilot study of behavior responses in young riding horses using 2 methods of making transitions from trot to walk. Journal of Veterinary Behavior: Clinical Applications and Research 7, 157-168.

Evans, J.W., Borton, A., Fintz, H.F., VanVleck, L.D., 1977. The Horse. W.H.Freeman \& Company, San Francisco.

Fazio, E., Medica, P., Cravana, C., Ferlazzo, A., 2013. Hypothalamic-pituitary-adrenal axis responses of horses to therapeutic riding program: Effects of different riders. Physiology and Behavior 118, 138-143.

Ferlazzo, A., Medica, P., Cravana, C., Fazio, E., 2012. Circulating $\beta$-Endorphin, Adrenocorticotropin, and Cortisol Concentrations of Horses Before and After Competitive Show Jumping with Different Fence Heights. Journal of Equine Veterinary Science.

Fleming, P.A., Paisley, C.L., Barnes, A.L., Wemelsfelder, F., 2013. Application of Qualitative Behavioural Assessment to horses during an endurance ride. Applied Animal Behaviour Science 144, 80-88.

Foley, K.M., Kourides, I.A., Inturrisi, C.E., Kaiko, R.F., Zaroulis, C.G., Posner, J.B., Houde, R.W., Li, C.H., 1979. beta-Endorphin: analgesic and hormonal effects in humans. Proceedings of the National Academy of Sciences of the United States of America 76, 5377-5381.

Freire, R., Buckley, P., Cooper, J.J., 2009. Effects of different forms of exercise on post inhibitoray rebound and unwanted behaviour in stabled horses. Equine Veterinary Journal, 41, 487-492. 
Friedman, B.H., Thayer, J.F., 1998. Anxiety and autonomic flexibility: a cardiovascular approach. Biological Psychology 47, 243-263.

Fureix, C., Beaulieu, C., Argaud, S., Rochais, C., Quinton, M., Henry, S., Hausberger, M., Mason, G., 2015. Investigating anhedonia in a non-conventional species: Do some riding horses Equus caballus display symptoms of depression? Applied Animal Behaviour Science 162, 26-36.

Fureix, C., Jego, P., Henry, S., Lansade, L., Hausberger, M., 2012. Towards an Ethological Animal Model of Depression? A Study on Horses. PLoS ONE 7, e39280.

Gehrke, E.K., Baldwin, A., Schiltz, P.M., 2011. Heart Rate Variability in Horses Engaged in Equine-Assisted Activities. Journal of Equine Veterinary Science 31, 78-84.

Gerber, M., Brand, S., Lindwall, M., Elliot, C., Kalak, N., Herrmann, C., Pühse, U., Jonsdottir, I.H. 2012. Concerns regarding hair cortisol as a biomarker of chronic stress in exercise and sport science. Journal of Sports Science and Medicine 11: 571-581.

Gillham, S.B., Dodman, N.H., Shuster, L., Kream, R., Rand, W., 1994. The effect of diet on cribbing behavior and plasma [beta]-endorphin in horses. Applied Animal Behaviour Science 41, 147-153.

Goldsmith, R.L., Bloomfield, D., Rottman, J., Bigger, J.T., 1993. Heart rate variability: Disagreement on the markers of sympathetic and parasympathetic activities. Journal of the American College of Cardiology. 22, 951-954.

Gordon, M.E., McKeever, K.H., Betros, C.L., Manso Filho, H.C. 2007. Exercise-induced alterations in plasma concentrations of ghrelin, adiponectin, leptin, glucose, insulin, and cortisol in horses. The Veterinary Journal 173: 532-540.

Górecka-Bruzda, A., Jastrzebska, E., Muszynska, A., Jedrzejewska, E., Jaworski, Z., Jezierski, T., 2011. Do horses like to jump? Strategies used by leisure and sport horses. Proceedings of the 7 th International Equitation Science Conference, 31.

Górecka-Bruzda, A., Jastrzębska, E., Muszyńska, A., Jędrzejewska, E., Jaworski, Z., Jezierski, T., Murphy, J., 2012. To jump or not to jump? Strategies employed by leisure and sport horses. Journal of Veterinary Behavior: Clinical Applications and Research.

Górecka-Bruzda, A., Kosińska, I., Jaworski, Z., Jezierski, T., Murphy, J., 2015. Conflict behavior in elite show jumping and dressage horses. Journal of Veterinary Behavior: Clinical Applications and Research 10, 137-146.

Górecka-Bruzda, A., Suwala, M., Jezierski, T., 2012. Typical artefacts in equine heart rate. Proceedings of the Annual Meeting of the International Society for Equitation Science, 66.

Górecka, A., Bakuniak, M., Chruszczewski, M.H., Jezierski, T.A., 2007. A note on the habituation to novelty in horses: handler effect. Animal Science Papers and Reports 25, 143-152.

Grillon, C., Baas, J., 2003. A review of the modulation of the startle reflex by affective states and its application in psychiatry. Clinical Neurophysiology 114, 1557-1579.

Grzimek, B., 1944. Scheuversuche mit Pferden. Zeitschrift fur Tierpsychologie 6, 26-40.

Hainsworth, R., 1995. The Control and Physiological Importance of Heart Rate, in: Malik, M., Camm, A.J. (Eds.), Heart Rate Variability, Futura Publishing Company, Inc., Armonk, pp. 3-19.

Hall, C., Goodwin, D., Heleski, C., Randle, H., Waran, N., 2008. Is There Evidence of Learned Helplessness in Horses? Journal of Applied Animal Welfare Science 11, 249-266.

Hall, C., Burton, K., Maycock, E. and Wragg, E. 2011. A preliminary study into the use of infrared thermography as a means of assessing the horse's response to different training methods. .Journal of Veterinary Behavior.6. 291-292.

Hall, C., Kay, R., Yarnell, K., 2014. Assessing ridden horse behavior: Professional judgment and physiological measures. Journal of Veterinary Behavior: Clinical Applications and Research 9, 2229.

Harber, V.J., Sutton, J.R., 1984. Endorphins and exercise. Sports medicine (Auckland, N.Z.) 1, 154-171.

Hartmann, E., Christensen, J.W., Keeling, L.J., 2011. Training young horses to social separation: effect of a companion horse on training efficiency. Equine Veterinary Journal 43, 580-584. 
Heleski, C.R., McGreevy, P.D., Kaiser, L.J., Lavagnino, M., Tans, E., Bello, N., Clayton, H.M., 2009. Effects on behaviour and rein tension on horses ridden with or without martingales and rein inserts. The Veterinary Journal 181, 56-62.

Henderson, A.J.Z., 2007. Don't fence me in: Managing psychological well being for elite performance horses. Journal of Applied Animal Welfare Science 10, 309-329.

Honess, P. E.and Marin, C. M. (2006). Behavioural and physiological aspects of stress and aggression in nonhuman primates. Neuroscience And Biobehavioral Reviews, 30(3), 390-412.

Hopster, H., Blokhuis, H.J., 1994. Validation Of A Heart-Rate Monitor For Measuring A Stress-Response In Dairy-Cows. Canadian Journal Of Animal Science 74, 465-474.

Hothersall, B., Casey, R., Undesired behaviour in horses: A review of their development, prevention, management and association with welfare. Equine Veterinary Education.

Ille, N., von Lewinski, M., Erber, R., Wulf, M., Aurich, J., Mőstl, E., Aurich, C. 2013. Effets of level of experience of horses and their riders on cortisol release, heart rate and heart-rate variability during a jumping course. Animal Welfare 22: 457-465.

Irvine, C.H.G., Alexander, S.L., 1994. Factors Affecting The Circadian-Rhythm In Plasma-Cortisol Concentrations In The Horse. Domestic Animal Endocrinology 11, 227-238.

Ito, N., Ito, T., Kromminga, A., Bettermann, A., Takigawa, M., Kees, F., Straub, R.H., Paus, R., 2005. Human hair follicles display a functional equivalent of the hypothalamic-pituitary-adrenal axis and synthesize cortisol. FASEB journal : official publication of the Federation of American Societies for Experimental Biology 19, 1332-1334.

Janczarek, I., Stachurska, A., Kedzierski, W., Wilk, I., 2013. Responses of horses of various breeds to a sympathetic training method. Journal of Equine Veterinary Science 33, 794-801.

Johnson, S.R., Rao, S., Hussey, S.B., Morley, P.S., Traub-Dargatz, J.L. 2011. Thermographic eye temperature as an index to body temperature in poinies. Journal of equine Veterianry Science. 31, 63-66.

Kaiser, L., Heleski, C.R., Siegford, J., Smith, K.A., 2006. Stress-related behaviors among horses used in a therapeutic riding program. Journal of the American Veterinary Medical Association 228, 39-45.

Kedzierski, W., Janczarek, I., Stachurska, A., 2012 Emotional response of naïve purebred Arabian colts and fillies to sympathetic and traditional training methods. Journal of Equine Veterinary Science 32, 752-756.

Keeling, L.J., Jonare, L., Lanneborn, L., 2009. Investigating horse-human interactions: The effect of a nervous human. The Veterinary Journal 181, 70-71.

Kienapfel, K., 2011. And what are the opinions of the horses? - On the expressive behaviour of horses in different neck positions. Pferdeheilkunde 27, 372-380.

Kienapfel, K., Link, Y., König v. Borstel, U., 2014. Prevalence of Different Head-Neck Positions in Horses Shown at Dressage Competitions and Their Relation to Conflict Behaviour and Performance Marks. PLoS ONE 9, e103140.

König v. Borstel, U., 2013. Assessing and influencing personality for improvement of animal welfare: a review of equine studies. CAB Reviews: Perspectives in Agriculture, Veterinary Science, Nutrition and Natural Resources 8, 1-27.

König von Borstel, U., Euent, S., Graf, P., König, S., Gauly, M., 2011. Equine behaviour and heart rate in temperament tests with or without rider or handler. Physiology \& Behavior 104, 454-463.

König von Borstel, U., Glißman, C., 2014. Alternatives to conventional evaluation of rideability in horse performance tests: suitability of rein tension and behavioural parameters. PLoS ONE 9, e87285.

König von Borstel, U., Keil, J., 2012. Horses' behavior and heart rate in a preference test for shorter and longer riding bouts. Journal of Veterinary Behavior: Clinical Applications and Research 7, 362374.

König von Borstel, U., McGreevy, P.D., 2014. Behind the vertical and behind the times. The Veterinary Journal 202, 403-404. 
Koolhaas, JM., de Boer, S.F., Buwalda, B., van Reenen, K., 2007 Individual variation in coping with stress: a multidimensional approach of ultimate and proximate mechanisms. Brain, Behaviour and Evolution, 70, 218-226

Kurvers, C.M.H.C., van Weeren, P.R., Rogers, C.W., van Dierendonck, M.C., 2006. Quantification of spontaneous locomotion activity in foals kept in pastures under various management conditions. American Journal of Veterinary Research 67, 1212-1217.

Kuwahara, M., Hashimoto, S.-i., Ishii, K., Yagi, Y., Hada, T., Hiraga, A., Kai, M., Kubo, K., Oki, H., Tsubone, H., Sugano, S., 1996. Assessment of autonomic nervous function by power spectral analysis of heart rate variability in the horse. Journal of the Autonomic Nervous System 60, 43-48.

Kuwahara, M., Hiraga, A., Kai, M., Tsubone, H., Sugano, S., 1999. Influence of training on autonomic nervous function in horses: evaluation by power spectral analysis of heart rate variability. Equine Veterinary Journal 31, 178-180.

Ladewig, J., Smidt, D., 1989. Behavior, Episodic Secretion of Cortisol, and Adrenocortical Reactivity in Bulls Subjected to Tethering. Hormones and Behavior 23, 344-360.

Lalanza, J. F., Sanchez-Roige, S., Cigarroa, I., Gagliano, H., Fuentes, S., Armario, A., Capdevila, L.,Escorihuela, R. M. (2015). Long-term moderate treadmill exercise promotes stress-coping strategies in male and female rats. Scientific Reports, 5,16166

Landis, C., Hunt, W.A., 1939. The startle pattern. Farrar and Rinehart Inc, New York.

Lansade, L., Bertrand, M., Boivin, X., Bouissou, M.F., 2004. Effects of handling at weaning on manageability and reactivity of foals. Applied Animal Behaviour Science 87, 131-149.

Laudenslager, M.L., Ryan, S.M., Drugan, R.C., Hyson, R.L., Maier, S.F., 1983. Coping and immunosuppression: inescapable but not escapable shock suppresses lymphocyte proliferation. Science (New York, N.Y.) 221, 568-570.

Lee, J., Floyd, T., Erb, H., Houpt, K., 2011. Preference and demand for exercise in stabled horses. Applied Animal Behaviour Science 130, 91-100.

Lesimple, C., Fureix, C., Menguy, H., Hausberger, M., (2010). Human Direct Actions May Alter Animal Welfare, a Study on Horses (Equus caballus). PLoS ONE 5(4): e10257.

Levenson, R.W., Wagner, H.L., 1988. Emotion and the autonomic nervous system: a prospectus for research on autonomic specificity, in: Anonymous (Ed.), Social psychophysiology and emotion : theory and clinical applications, Wiley, Chichester ; Toronto, pp. 17-42.

Levine, J.A., Pavlidis, I., Cooper, M., 2001. The face of fear. The Lancet. 357, 1757.

Linden, A., Art, T., Amory, H., Desmecht, D., Lekeux, P., 1991. Effect of 5 different types of exercise, transportation and ACTH administration on plasma cortisol concentration in sport horses. Equine Exercise Physiology, 391-396.

Malinowski, K., Shock, E.J., Rochelle, P., Kearns, C.F., Guirnalda, P.D., McKeever, K.H., 2006. Plasma betaendorphin, cortisol and immune responses to acute exercise are altered by age and exercise training in horses. Equine Vet J Suppl 38, 267-273.

Malliani, A., 1995. Association of heart rate variability components with physiologcial regulatory mechanisms, in: Malik, M., Camm, A.J., Armonk, N.Y. (Eds.), Heart Rate Variability, Futura, pp. 173-188.

Mars, L.A., Kiesling, H.E., Ross, T.T., Armstrong, J.B., Murray, L., 1992. Water acceptance and intake in horses under shipping stress. Journal of Equine Veterinary Science 12, 17-20.

Mason, G., \& Mendl, M. (1993). Why is there no simple way of measuring animal welfare? Animal Welfare, 2, 301-319.

Mata, F., Johnson, C., Bishop, C., 2015. A Cross-Sectional Epidemiological Study of Prevalence and Severity of Bit-Induced Oral Trauma in Polo Ponies and Race Horses. Journal of Applied Animal Welfare Science 18, 259-268.

McBride, S. D., \& Cuddeford, D. (2001). The putative welfare-reducing effects of preventing equine stereotypic behaviour. Animal Welfare, 10(2), 173-189 
McCarthy, R.N., Jeffcott, L.B., Clarke, I.J., 1993. Preliminary studies on the use of $\hat{\imath}^{2}$-endorphin in horses as an indicator of stress and pain. Journal of Equine Veterinary Science 13, 216-219.

McGreevy PD, French NP, Nicol CJ (1995) The prevalence of abnormal behaviours in dressage, eventing and endurance horses in relation to stabling. Vet Rec 137. 36-37

McGreevy, P., Nicol, C., 1998. Physiological and behavioral consequences associated with short-term prevention of crib-biting in horses. Physiology \& Behavior 65, 15-23.

McGreevy, P.D., McLean, A.N., 2010. Equitation Science. Wiley-Blackwell, Oxford, UK.

McGreevy, P., Warren-Smith, A., Guisard, Y. 2012. The effect of double bridles and jaw-clamping crank nosebands on temperature of eyes and facial skin of horses. Journal of Veterinary Behavior. 7, 142-148.

Medica, P., Cravana, C., Fazio, E., Ferlazzo, A., 2011. Hormonal responses of Quarter Horses to a 6-week conventional Western-riding training programme. Livestock Science 140, 262-267.

Medill, S.A., Janz, D.A., McLoughlin, P.D., 2015. Hair testosterone and cortisol concentrations and their| relationships to physiological and social status in feral horses (Equus ferus caballus). Proceedings of the 3rd International Equine Science Meeting 2015, 21.

Merl, S., Scherzer, S., Palme, R., Mőstl, E. 2000. Pain causes increased concentrations of glucocorticoid metabolites in horse feces. Journal of Equine Veterinary Science 20: 586-590.

Mills, P.C., Ng, J.C., Kramer, H., Auer, D.E. 1997. Stress response to chronic inflammation in the horse. Equine Veterinary Journal 29: 483-486.

Moons, C.P.H., Laughlin, K., Zanella, A.J., 2005. Effects of short-term maternal separations on weaning stress in foals. Applied Animal Behaviour Science 91, 321-335.

Munsters, C.C.B.M., van den Broek, J., van Weeren, R., Sloet van Oldruitenborgh-Oosterbaan, M.M., 2013. The effects of transport, riot control training and night patrols on the workload and stress of mounted police horses. Applied Animal Behaviour Science 143, 52-60.

Munsters, C.C.B.M., Visser, K.E.K., van den Broek, J., Sloet van Oldruitenborgh-Oosterbaan, M.M., 2012. The influence of challenging objects and horse-rider matching on heart rate, heart rate variability and behavioural score in riding horses. Veterinary journal (London, England : 1997) 192, 75-80.

Myrtek, M., 2004. Heart and emtion: ambulatory monitoring studies in everyday life. Hogrefe \& Huber, Toronto, Canada.

Myrtek, M., Aschenbrenner, E., Brugner, G., 2005. Emotions in everyday life: an ambulatory monitoring study with female students. Biological Psychology 68, 237-255.

Nakayama, K., Goto, S., Kuraoka, K., Nakamura, K. 2005. Decrease in nasal temperature of rhesus monkeys (Macaca mulatta) in negative emotional state. Physiology and Behavior. 84, 783-790.

Niinistö, K.E., Korolainen, R.V., Raekallio, M.R., Mykkänen, A.K., Koho, N.M., Ruohoniemi, M.O., Leppäluoto, J., Reeta Pösö, A., 2010. Plasma levels of heat shock protein 72 (HSP72) and $\beta$ endorphin as indicators of stress, pain and prognosis in horses with colic. Veterinary Journal 184, 100-104.

Normando, S., E. Canali, et al. (2002). Behavioral problems in Italian saddle horses. Journal of Equine Veterinary Science 22(3): 117-120.

Oka, T., Hori, T., 2001. Mechanisms and mediators of psychological stress-induced rise in core temperature. Psychosomatic Medicine. 63, 476-486.

Palme, R., 2015. Non-invasive monitoring of stress hormones for welfare assessment in domestic and wild equids. Proceedings of the 3rd International Equine Science Meeting 2015, 3.

Parker, M., Goodwin, D., Eager, R.A., Redhead, E.S., Marlin, D.J., 2009. Comparison of Polar ${ }^{\circledR}$ heart rate interval data with simultaneously recorded ECG signals in horses. Comparative Exercise Physiology 6, 137-142.

Parker, M., Goodwin, D., Eager, R.A., Redhead, E.S., Marlin, M., 2010. Comparison of PolarW heart rate interval data with simultaneously recorded ECG signals in horses. Comparative Exercise Physiology 6, 137-142. 
Pasing, S., von Lewinski, M., Wulf, M., Erber, R., Aurich, C., 2013. Influence of semen collection on salivary cortisol release, heart rate, and heart rate variability in stallions. Theriogenology $80,256-$ 261.

Pavlidis, I., Eberhardt, N.I., Levine, J.A., 2002. Seeing through the face of deception. Nature. 415, 35.

Peeters, M., Closson, C., Beckers, J.F., Vandenheede, M., 2013. Rider and Horse Salivary Cortisol Levels During Competition and Impact on Performance. Journal of Equine Veterinary Science 33, 155160.

Physick-Sheard, P.W., Marlin, D.J., Thornhill, R., Schroter, R.C., 2000. Frequency domain analysis of heart rate variability in horses at rest and during exercise. Equine Veterinary Journal 32, 253-262.

Pierard, M., Hall, C., König von Borstel, U., Averis, A., Hawson, L., McLean, A., Nevison, C., Visser, K., McGreevy, P., Evolving protocols for research in equitation science. Journal of Veterinary Behavior: Clinical Applications and Research 10, 255-266.

Popot, M.A., Houghton, E., Ginn, A., Jones, M., Teale, P., Samuels, T., Lassourd, V., Dunnett, N., Cowan, D.A., Bonnaire, Y., Toutain, P.L., 1997. Cortisol concentrations in post competition horse urine: A French and British survey. Equine Veterinary Journal 29, 226-229.

Powell, D.M., Bennett-Wimbush, K., Peeples, A., Duthie, M., 2008. Evaluation of Indicators of WeightCarrying Ability of Light Riding Horses. Journal of Equine Veterinary Science 28, 28-33.

Quick, J.S., Warren-Smith, A.K., 2009. Preliminary investigations of horses' (Equus caballus) responses to different bridles during foundation training. Journal of Veterinary Behavior: Clinical Applications and Research 4, 169-176.

Ralston, J. M., Stenhouse, A. M., Stenhouse, N. S., Buck, G. J., Lucks, S. F., Reynoldson, J. A., \& Bolton, J. R. (1988). Cortisol concentrations in blood and urine of horses. Australian Veterinary Journal, 65(1), 1-5.

Rammerstorfer, C., Potter, G.D., Brumbaugh, G.W., Gibbs, P.G., Varner, D.D., Rammerstorfer, E.H., 2001. Physiologic responses of acclimatized or non-acclimatized mature reining horses to heat stress: I. Journal of Equine Veterinary Science 21, 431-438.

Rietmann, T.R., Stauffacher, M., Bernasconi, P., Auer, J.A., Weishaupt, M.A., 2004a. The association between heart rate, heart rate variability, endocrine and behavioural pain measures in horses suffering from laminitis. Journal Of Veterinary Medicine Series A-Physiology Pathology Clinical Medicine 51, 218-225.

Rietmann, T.R., Stuart, A.E.A., Bernasconi, P., Stauffacher, M., Auer, J.A., Weishaupt, M.A., 2004b. Assessment of mental stress in warmblood horses: heart rate variability in comparison to heart rate and selected behavioural parameters. Applied Animal Behaviour Science 88, 121-136.

Rivera, E., Benjamin, S., Nielsen, B., Shelle, J., Zanella, A.J., 2002. Behavioral and physiological responses of horses to initial training: the comparison between pastured versus stalled horses. Applied Animal Behaviour Science 78, 235-252.

Robson, P.J., Alston, T.D., Myburgh, K.H., 2003. Prolonged suppression of the innate immune system in the horse following an $80 \mathrm{~km}$ endurance race. Equine Veterinary Journal 35, 133-137.

Rushen, J., 1986. Some problems with the physiological concept of "stress". Australian Veterinary Journal 63, 359-360.

Sandem, A.I., Janczak, A.M., Braastad, B.O., 2004. A short note on effects of exposure to a novel stimulus (umbrella) on behaviour and percentage of eye-white in cows. Applied Animal Behaviour Science 89, 309-314.

Schmidt, A., J. Aurich, Mostl, E., Muller, J., Aurich, C. (2010). Changes in cortisol release and heart rate and heart rate variability during the initial training of 3-year-old sport horses. 58(4): 628-636.

Sloet van Oldruitenborgh-Oosterbaan, M.M., Blok, M.B., Begeman, L., Kamphuis, M.C.D., Lameris, M.C., Spierenburg, A.J., Lashley, M.J.J.O., 2006. Workload and stress in horses: comparison in horses ridden deep and round ('rollkur') with a draw rein and horses ridden in a natural frame with only light rein contact. Tijdschrift voor Diergeneeskunde 131, 114-119. 
Smiet, E., Van Dierendonck, M.C., Sleutjens, J., Menheere, P.P.C.A., van Breda, E., de Boer, D., Back, W., Wijnberg, I.D., van der Kolk, J.H., 2014. Effect of different head and neck positions on behaviour, heart rate variability and cortisol levels in lunged Royal Dutch Sport horses. The Veterinary Journal 202, 26-32.

Squires, E.J., 2003. Applied Animal Endocrinology. CABI, Wallingford, Oxon, UK.

Stegman and Jones 1998. Perioperative plasma cortisol concentrations in the horse. Journal of the South African Veterinary Association 69: 137-142

Stein, P.K., Bosner, M.S., Kleiger, R.E., Conger, B.M., 1994. Heart rate variability: a measure of cardiac autonomic tone. American heart journal 127, 1376-1381.

Stewart, M., Webster, J.R., Verkerk, G.A., Schaefer, A.L., Colyn, J.J., Stafford, K.J., 2007. Non-invasive measurement of stress in dairy cows using infrared thermography. Physiology and Behavior. 92, 520-525.

Tartaglia, L., Waugh, A., 2002. Veterinary physiology and applied anatomy : a textbook for veterinary nurses and technicians. Butterworth-Heinemann : College of Animal Welfare, Oxford.

Task Force of the European Society of Cardiology, North American Society of Pacing and Electrophysiology, 1996. Heart rate variability: standards of measurement, physiological interpretation, and clinical use Circulation 93, 1043-1065

Thayer, J.F., Hahn, A.W., Sollers, J.J., Van Doornen, L., Johnson, P.J., 1997. Heart rate variability in the horse by ambulatory monitoring. Biomedical Sciences Instrumentation 33, 482-485.

Tiller, W.A., McCraty, R., Atkinson, M., 1996. Cardiac coherence: a new, noninvasive measure of autonomic nervous system order. Alternative Therapies in Health and Medicine 2, 52-65.

Valera, M., Bartolomé, E., Sánchez, M.J., Molina, A., Cook, N., Schaefer, A. 2012. Changes in eye temperature and stress assessment in horses during show jumping competitions. Journal of Equine Veterinary Science. 32, 827-830.

van Breda, E., 2006. A nonnatural head-neck position (RollkÃ $1 / 4$ r) during training results in less acute stress in elite, trained dressage horses. Journal of Applied Animal Welfare Science 9, 59-64.

VanderHorst, K.J., Rijksen, L., Ariëns, J., VanRiet, A., Timmerman, M., Schreuder, M., Visser, K., 2013. The effect of type of bit on welfare and performance of horses. Journal of Veterinary Behavior: Clinical Applications and Research 8, e22.

Van Reenen, C.G., Mars, M.H., Leushuis, I.E., Rijsewijk, F.A.M., Van Oirschot, J.T., Blokhuis, H.J., 2000. Social isolation may influence responsiveness to infection with bovine herpesvirus 1 in veal calves. Vet. Microbiol. 75 (2),135-143.

Visser, E., van Reenen, C., Hopster, H., Schilder, M., Knaap, J., Barneveld, A., Blokhuis, H., 2001. Quantifying aspects of young horses' temperament: consistency of behavioral variables. Applied Animal Behaviour Science 74, 241 - 258.

Visser, E.K., 2002. Horsonality: a study on the personality of the horse, Utrecht University, Utrecht, The Netherlands, p. 151.

Visser, E.K., Ellis, A.D., Van Reenen, C.G., 2008. The effect of two different housing conditions on the welfare of young horses stabled for the first time. Applied Animal Behaviour Science 114, 521533.

Visser, E.K., van Reenen, C.G., van der Werf, J.T.N., Schilder, M.B.H., Knaap, J.H., Barneveld, A., Blokhuis, H.J., 2002. Heart rate and heart rate variability during a novel object test and a handling test in young horses. Physiology \& Behavior 76, 289-296.

Visser, E. K., Neijenhuis, F., de Graaf-Roelfsema, E., Wesselink, H. G. M., de Boer, J., van Wijhe-Kiezebrink, M. C., van Reenen, C. G. (2014). Risk factors associated with health disorders in sport and leisure horses in the Netherlands. Journal of Animal Science, 92(2), 844-855.

Voith, V.L., 1979. Treatment of fear-induced aggression in a horse. Modern Veterinary Practice 60, 835837. 
von Borell, E., Langbein, J., Després, G., Hansen, S., Leterrier, C., Marchant-Forde, J., Marchant-Forde, R., Minero, M., Mohr, E., Prunier, A., Valance, D., Veissier, I., 2007. Heart rate variability as a measure of autonomic regulation of cardiac activity for assessing stress and welfare in farm animals - A review. Physiology \& Behavior 92, 293-316.

von Borstel, U., König, S. , 2008. Effect of rider relaxation on horse behaviour and heart rate Proceedings of the 59th Annual Meeting of the European Association for Animal Production, 173.

von Borstel, U., Pasing, S., Gauly, M., 2011. Towards a more objective assessment of equine personality using behavioral and physiological observations from performance test training. Applied Animal Behaviour Science 135, 277 - 285.

von Borstel, U.U., 2008. Fear in Horses and Riders: Two Hearts Living in just One Mind - The Influence of Rider, Training and Genetics on horses' fear. Verlag Dr. Müller, Saarbrücken, Germany.

von Borstel, U.U., Duncan, I.J.H., Shoveller, A.K., Merkies, K., Keeling, L.J., Millman, S.T., 2009. Impact of riding in a coercively obtained Rollkur posture on welfare and fear of performance horses. Applied Animal Behaviour Science 116, 228-236.

von Lewinski, M., Biau, S., Erber, R., Ille, N., Aurich, J., Faure, J.M., Möstl, E., Aurich, C., 2013. Cortisol release, heart rate and heart rate variability in the horse and its rider: Different responses to training and performance. Veterinary Journal 197, 229-232.

Waran, N. K., Leadon, D., \& Friend, T. H. (2002). The effects of transportation on the welfare of horses Animal Welfare (pp. 125-150): Springer Netherlands Kluwer Academic Publishers.

Wagner, A.E., 2010. Effects of stress on pain in horses and incorporating pain scales for equine practice. Veterinary Clinics of North America, Equine Practice 26, 481-492.

Wiepkema PR, Schouten WG (1992) Stereotypies in sows during chronic stress. Psychotherapy and Psychosomatics. 57: 194-199.

Witzmann, P., 2014. Die richtlinienkonforme Verschnallung der Zäumung. Proceedings of the 1. Pferdetage Baden-Württemberg, 33.

Yarnell, K., Hall, C., Billett, E., 2013. An assessment of the aversive nature of an animal management procedure (clipping) using behavioral and physiological measures. Physiology \& Behavior 118, 32-39.

Young, T., Creighton, E., Smith, T., Hosie, C., 2012. A novel scale of behavioural indicators of stress for use with domestic horses. Applied Animal Behaviour Science 140, 33-43.

Zebisch, A., May, A., Reese, S., Gehlen, H., 2014. Effect of different head-neck positions on physical and psychological stress parameters in the ridden horse. J Anim Physiol Anim Nutr (Berl) 98, 901-907. 